Notre Dame Law School

NDLScholarship

Journal Articles

Publications

2014

\title{
Shared Parenting Laws: Mistakes of Pooling?
}

Margaret F. Brinig

Notre Dame Law School, mbrinig@nd.edu

Follow this and additional works at: https://scholarship.law.nd.edu/law_faculty_scholarship Part of the Family Law Commons

\section{Recommended Citation}

Margaret F. Brinig, Shared Parenting Laws: Mistakes of Pooling?, Notre Dame Legal Studies Paper No. 1426 (August 14, 2014). Available at: https://scholarship.law.nd.edu/law_faculty_scholarship/1116

This Article is brought to you for free and open access by the Publications at NDLScholarship. It has been accepted for inclusion in Journal Articles by an authorized administrator of NDLScholarship. For more information, please contact lawdr@nd.edu. 
Shared Parenting Laws: Mistakes of Pooling?

Margaret F. Brinig, Notre Dame Law School

In their recent paper "Anti-Herding Regulation," forthcoming in the Harvard Business Review, ${ }^{1}$ Ian Ayres and Joshua Mitts argue that many well-intentioned public policy regulations potentially harm rather than help situations. That is, because the rules seek to pool - or herd - groups of people, treating them as equal, they miss or mask important differences among the regulated, thus magnifying systematic risk. Antiherding regulation, on the other hand, can produce socially beneficial information, in their words steering "both private and public actors toward better evidence-based outcomes." Left to their own, or with various carrot-and-stick incentives, some groups, anyway, would instead fare better if allowed to separate or diverge.

Ayres and Mitts buttress their case with examples from engineering (bridges collapsing because soldiers crossed them in cadences matched to the structures' oscillations), finance (mandating only low percentages down for real estate purchasers), biodiversity and ecosystem stability, and genetic variation itself. They conclude with various suggestions based on menu approaches and systems design theory.

The need for anti-herding law might also apply to certain (common law/judicial) contexts - including, this article argues, child custody decisions. Typically and for separation of powers considerations, courts and the court process conduct a structurally different role from administrative agencies. However, when the legislature or a higher court devises a presumption that regulates conduct, judges are not as free to use their discretion in interpreting the law as they usually are, particularly as they would be with an opened-ended goal like deciding custody "in the best interests of the child." What child custody statutes with presumptions do is to assume that the road to the "best interests" of each child is the same: that is, that a single solution will prove to be best for all children. In the law and economics framework of Ayres and Mitts, the statutes promote a "pooling" rather than a "separating" equilibrium. ${ }^{2}$

In purely financial or commercial settings, this sort of forcing may not be inappropriate, and may in fact be constitutionally necessary (under the equal protection clause, for example, historically disadvantaged groups cannot without good and permissible reason be treated differently). ${ }^{3}$ However, with very few exceptions (such as

\footnotetext{
$1 \quad$ Anti-Herding Regulation, John M. Olin Center for Studies in Law, Economics, and Public Policy, Research Paper No. 490 (Yale Law School, 2014), forthcoming 4 HARVARD BUS. L. REV. - (2014).

2 In contrast, something like a lottery or randomized solution would produce separation, though a much better solution for individual children might do much better. See NEIL DUXBURY, RANDOM JUSTICE; ON LOTTERIES AND LEGAL DECISION-MAKING 93 (2002)(“Whatever other advantages or drawbacks might attach to determining child custody by the flipping of a coin, there seems to be no doubt that the idea brings with it... a negative symbolic resonance"); Jon Elster, Solomonic Judgments: Against the Best Interest of the Child, 54 U. CHI. L. REV. 1,5 (1987. In fiction, see HENRY JAMES, WhAT MAISIE KNEW (1897).

3 See, e.g., Paul Brest, Forward: In Defense of the Antidiscrimination Principle, 90 HARV. L. REV. 1 (1970).
} 
for Native Americans under the Indian Child Welfare Act), ${ }^{4}$ whole groups of children cannot be forced into similar parenting situations ${ }^{5}$ as long as parents are acting within the quite broad variance given to "fitness." It is this type of pooling that may in fact threaten systematic risk for those children least likely to have resources to cope with them - those whose parents cannot get along even to the extent of co-parenting well, or where there are the barriers to trust posed by such conditions as substance abuse, ${ }^{7}$ mental illness ${ }^{8}$ or coercive-control intimate partner violence, ${ }^{9}$ or even where the parents struggled to maintain a viable financial life when living in a single household, now divided into two. A stronger objection, perhaps, is both that the presumption denies information to other separating parents (according to the Ayres and Mitts framework), a possibility we will consider later, and that the presumption itself may be ill conceived for at least a large number of families. ${ }^{10}$

Presumptions in child custody are naturally disfavored by three groups - the judges who lose their discretion and seemingly a part of their "raison d'être" (though deciding contested custody cases is difficult and uncomfortable), the helping professionals who otherwise would assist in making determinations based on "best interests," and whatever group is disfavored by the particular way the presumption is set.

4 The Indian Child Welfare Act of 1978, 25 U.S.C . $\S 1901-1963 . \S 1901$ (5) recognizes that "the States, exercising their recognized jurisdiction over Indian child custody proceedings through administrative and judicial bodies, have often failed to recognize the essential tribal relations of Indian people and the cultural and social standards prevailing in Indian communities and families."

See Mississippi Band of Choctaw Indians v. Holyfield, 490 U.S. 30 (1989), in which Justice Brennan, writing for the majority, noted that "Tribal jurisdiction under $\S 1911(1)$ was not meant to be defeated by the actions of individual members of the tribe, for Congress was concerned not solely about the interests of Indian children and families, but also about the impact on the tribes themselves of the large numbers of Indian children adopted by non-Indians..." Id. at 49. "It is not ours to say whether the trauma that might result from removing these children from their adoptive family should outweigh the interest of the Tribe - and perhaps the children themselves - in having them raised as part of the Choctaw community. Id at 54. ICWA gives preference to tribal or Indian families, but operates primarily by vesting jurisdiction in tribal rather than state courts.

$6 \quad$ See, e.g., Troxel v. Granville, 530 U.S. 57, 66 (2000)(“it cannot now be doubted that the Due Process Clause of the Fourteenth Amendment protects the fundamental right of parents to make decisions concerning the care, custody, and control of their children").

$7 \quad$ See, e.g., Nancy Suchman et al., Substance-Abusing Mothers and Disruptions in Child Custody: An Attachment Perspective, 30 J. SuBSTANCE ABUSE TREAT. 197 (2008).

$8 \quad$ See, e.g., Minn. Stat. $\$ 518.17$ provides for the court to consider "the mental and physical health of all individuals involved; except that a disability, as defined in section 363A.03, of a proposed custodian or the child shall not be determinative of the custody of the child, unless the proposed custodial arrangement is not in the best interest of the child."

9 See AMERICAN LAW InSTITUTE, PRINCIPLES OF FAMILY DiSSOLUTION $\$ 2.13$ (2002 (presuming that domestic violence situations are not presumably detrimental to being custodial parents.

Section 2.13 provides that the court shall limit or deny access and responsibility of a parent otherwise allocated responsibility under a parenting plan to secure the safety and welfare of the child or of a child's parent, where it finds that interests of the child would be served by such limit or denial, in light of credible evidence that the parent to be limited has "abused, neglected, or abandoned a child, as defined by state law; has inflicted domestic abuse, or allowed another to inflict domestic abuse.

10 See, e.g., Margaret F. Brinig, Penalty Defaults in Family Law: The Case of Child Custody, 33

FLA. ST. U.L. REV. 779 (2006) 
Custody rules, including the ones examined here, are generally set with a great deal of advocacy but without a great deal of empirical research behind them, and are rarely tested carefully to see whether justice to the individual affected children is being served. This paper presents an initial foray into such a test, looking at the effect of a strong child shared custody presumption on the behavior of parents and judges during and within five years of the original custody proceeding. There are limitations to this empirical approach: most of the case files do not provide close glimpses into what the parents were thinking at any given point in time, what arrangements judges would have ordered absent the presumption, or what professionals such as custody evaluators would have done differently. While my observations in each case begin with the initial filing in 2008 and end with the last filing in early 2014 (or before), they are not longitudinal in the sense that I can show causation. To obtain that sort of predictive ability, at minimum one would need to have a change in the law and cases from before and after the law took effect. It would also be helpful to have a "control" state with generally similar legal rules and social norms but where no such change in the law took place. Nonetheless, the ability to look at two counties (Maricopa and Pima) in the same state (Arizona) provides the opportunity to examine differences in implementation.

Even with these limitations, the picture is a mixed one: some couples do fine with shared custody, and are able to adjust over time without result to acrimonious processes. Their children are presumably better for the frequent and meaningful contact with both the parents. ${ }^{11}$ The successes must be weighed against another group of cases where, at best, shared parenting seems to take place at the price of considerable parental conflict and continued litigation. ${ }^{12}$ The emerging factual pattern seems to fit within Ayres and Mitts' prescription for a separating equilibrium, while the presumption, bolstered by strong community support (in Pima County, at any rate) ${ }^{13}$ for shared parenting, pushes for a pooling equilibrium highlighted by equally shared custody. Particularly troublesome (and unstable) are cases involving indications of domestic violence and/or substance abuse as well as those from the lower half of family incomes and the increasing number of unmarried couples affected by custody and child support orders.

I will proceed by describing the system of judicial discretion in custody proceedings as well as the current political struggle over custody standards and presumptions. I will then present the Ayres and Mitts model, and will continue with empirical findings from more than 1000 cases in two Arizona counties that together represent $70 \%$ of the population of the state, followed by a brief conclusion.

11 Accord, see Marsha Kline Pruett \& J. Herbie DiFonzo, Closing the Gap: Research, Policy, Practice and Shared Parenting, 52 FAM. CT. REV. 152, 154 (3) (2014) (Social science supports shared parenting when both parents agree to it).

12 Some of the costs of litigation are explored in Robert H., Mnookin \&Lewis Kornhauser, Bargaining in the Shadow of the Law: The Case of Divorce, 88 YALE L.J. 950 (1979) at 971-72.

13 Sanford Braver et al. Lay Judgments About Child Custody, 17 PSYCH. PUB. POL'Y \& L. 212 (2011) (jury pool candidates surveyed about what they thought was fair and what they would do given various scenarios; $69 \%$ were in favor of equal custody if each parent had done approximately the same amount of child care before separation, but this declined to $21 \%$ when the mother had done most of the child care or $27 \%$ where father had done most of the child care during the marriage). The answers were similar even where the couple was high conflict. 


\section{Custody Standards and Judicial Discretion}

Academics, especially those writing in family law, present child custody proceedings as exemplars of discretionary decisionmaking. ${ }^{14}$ Legislatures have long realized that dissolving families that present cases where judges must choose between fit parents need to be individualized, ${ }^{15}$ since each family presents its own unique characteristics. ${ }^{16}$ The goal is not to reward parents as much as to serve their children's needs. ${ }^{17}$ While children all need food, shelter and clothing, their individual emotional needs, medical requirements, and educational needs vary like snowflakes. While parents are the parties in custody proceedings, children are always the intended third party beneficiaries ${ }^{18}$ of whatever agreement the parents make or arrangement the court orders. Statutes are therefore typically drawn broadly to include the "best interests of the child" language, most with a list of factors to help guide courts. ${ }^{19}$ More recent legislative forays indicate

$14 \quad$ Robert H. Mnookin, Child-Custody Adjudication: Judicial Functions in the Face of Indeterminacy, 39 L. \& CONT. PROBS. 226, 250-51 (1975); Robert A. Burt, Experts, Custody Disputes, \& Legal Fantasies, 14 THE PSYCHIATRIC HOSPITAL 140 (19830; David .L Chambers, Rethinking the Substantive Rules for Custody Disputes in Divorce, 83 MicH. L. REV. 477, 491 (1984); Mary Ann Glendon, Fixed Rules and Discretion in Contemporary Family Law and Succession Law, 60 TULANE L. REV. 1165, 1181 (1986); Carl E. Schneider, Discretion, Rules, and Law: Child Custody and the UMDA's Best-Interest Standard, 89 MiCH. L. REV. 2215 (1991).

$15 \quad$ See finding 1 from Pruett \& DiFonzo, supra note 11 ("The most effective decision-making about parenting time after separation is inescapably case-specific"), and finding that "Statutory presumptions prescribing specific allocations of shared parenting time are unsupportable since no prescription will fit all, or even the majority of, families' particular circumstances."

16 As Schneider, supra note 12, acknowledges, judges act within the constraints of social norms as well as their legal training and the norms that training inculcates (Citing H.A. Finlay, Judicial Discretion in Family and Other Litigation, 2 MONASH L. REv. 221, 222 (1976)).

$17 \quad$ Statutes may state that the best interests of the child are the primary concern. See, e.g., Va. Code 124.2, Tex. Code $\S 153.002$; Wis. Stat. $\S 20-1242$. The ALI Principles, supra note 9, make this explicit, as $\S 2.02$ (2) (fairness to the parties is secondary). See also Marsha Garrison, Law Making for Baby Making: An Interpretative Approach to the Determination of Legal Parentage, 113 HARV. L. REV. 835, 893-94 (2000).

18 See, e.g., Drake v. Drake, 455 N.Y.S.2d 420 (N.Y. App. Div. 1982) (while child could sue directly for the college tuition or insurance prescribed in the parents' separation agreement, and was an intended beneficiary of the monthly support payments, only the mother had the ability to enforce the ongoing duty of support). Jill Hasday maintains that this retention of parental rights often conflicts with the children's interests. Jill Elaine Hasday, The Canon of Family Law, 57 STAN. L. REV. 825, 849-50 (2004).

$19 \quad$ Carl Schneider, supra note 12, suggests that this slightly cabined form of discretion (using guidelines or factors) seem to acknowledge the possible desirability of cabining discretion but the impossibility of doing so in any very confining way." See also the Uniform Marriage and Divorce Act (UMDA) §401 (now Model Marriage and Divorce Act); Minn. Stat. §518.17 (2013) provides in part: Subdivision 1.The best interests of the child. (a) "The best interests of the child" means all relevant factors to be considered and evaluated by the court including:

(1) the wishes of the child's parent or parents as to custody;

(2) the reasonable preference of the child, if the court deems the child to be of sufficient age to express preference;

(3) the child's primary caretaker;

(4) the intimacy of the relationship between each parent and the child;

(5) the interaction and interrelationship of the child with a parent or parents, siblings, and any other person who may significantly affect the child's best interests;

(6) the child's adjustment to home, school, and community; 
sine-like traverses across the best interests standard, with some presumptions (like the primary caretaker presumption and the ALI replication principle) largely favoring

(7) the length of time the child has lived in a stable, satisfactory environment and the desirability of maintaining continuity;

(8) the permanence, as a family unit, of the existing or proposed custodial home;

(9) the mental and physical health of all individuals involved; except that a disability, as defined in section 363A.03, of a proposed custodian or the child shall not be determinative of the custody of the child, unless the proposed custodial arrangement is not in the best interest of the child;

(10) the capacity and disposition of the parties to give the child love, affection, and guidance, and to continue educating and raising the child in the child's culture and religion or creed, if any;

(11) the child's cultural background;

(12) the effect on the child of the actions of an abuser, if related to domestic abuse, as defined in section 518B.01, that has occurred between the parents or between a parent and another individual, whether or not the individual alleged to have committed domestic abuse is or ever was a family or household member of the parent; and

(13) except in cases in which a finding of domestic abuse as defined in section 518B.01 has been made, the disposition of each parent to encourage and permit frequent and continuing contact by the other parent with the child.

The court may not use one factor to the exclusion of all others. The primary caretaker factor may not be used as a presumption in determining the best interests of the child. The court must make detailed findings on each of the factors and explain how the factors led to its conclusions and to the determination of the best interests of the child.

Similarly, Ariz. Stat. $25-403$ sets out a best interests standard as follows:

25-403. Legal decision-making; best interests of child

A. The court shall determine legal decision-making and parenting time, either originally or on petition for modification, in accordance with the best interests of the child. The court shall consider all factors that are relevant to the child's physical and emotional well-being, including:

1. The past, present and potential future relationship between the parent and the child.

2. The interaction and interrelationship of the child with the child's parent or parents, the child's siblings and any other person who may significantly affect the child's best interest.

3. The child's adjustment to home, school and community.

4. If the child is of suitable age and maturity, the wishes of the child as to legal decision-making and parenting time.

5. The mental and physical health of all individuals involved.

6. Which parent is more likely to allow the child frequent, meaningful and continuing contact with the other parent. This paragraph does not apply if the court determines that a parent is acting in good faith to protect the child from witnessing an act of domestic violence or being a victim of domestic violence or child abuse.

7. Whether one parent intentionally misled the court to cause an unnecessary delay, to increase the cost of litigation or to persuade the court to give a legal decision-making or a parenting time preference to that parent.

8. Whether there has been domestic violence or child abuse pursuant to section 25-403.03.

9. The nature and extent of coercion or duress used by a parent in obtaining an agreement regarding legal decision-making or parenting time.

10. Whether a parent has complied with chapter 3 , article 5 of this title.

11. Whether either parent was convicted of an act of false reporting of child abuse or neglect under section 13-2907.02.

B. In a contested legal decision-making or parenting time case, the court shall make specific findings on the record about all relevant factors and the reasons for which the decision is in the best interests of the child. 
mothers, ${ }^{20}$ while shared or equal-parenting presumptions, despite their non-gendered terminology, favor fathers who have played modest caretaking functions while the parents' relationship remained intact. ${ }^{21}$

While "best interests of the child" sounds like a neutral model, and has been the ostensible standard since the late $19^{\text {th }}$ century, ${ }^{22}$ over time it has taken on different content that has caused preferences to move between mother and father. Originally, since living in an intact marriage was presumed best for children, whoever caused that marriage to break was deemed unfit to care for the child. ${ }^{23}$ Living with the innocent parent therefore was in the child's best interests. By the early twentieth century, as first Freudian and then attachment theory took center stage in psychiatry and psychology, "best interests" meant living with one's mother for a child of tender years. ${ }^{24}$ Later, as constitutional cases made gendered presumptions suspect, and following publication of the important work of Freud, Goldstein and Solnit, Beyond the Best Interests of the Child, ${ }^{25}$ the standard morphed into living with one's "primary caretaker." Concerned about "the use of custody... being used in an abusive way as a coercive weapon to affect the level of support payments and the outcome of other issues in the underlying divorce" and "the urgent need... for a legal structure upon which a divorcing couple may rely in reaching a settlement," Justice Neely's opinion proposed that "the best interests of children would be best served by awarding them to the primary caretaker parent, regardless of sex." The so-called primary caretaker rule became the standard for about ten years in West Virginia, for a few years by statute in Minnesota, and as a factor in many more states' custody framework. ${ }^{26}$ Of course, because of prevailing mores, this results in mothers having custody and fathers visitation the vast majority of the time. ${ }^{27}$

20 See Katharine T. Bartlett, Re-Expressing Parenthood, 98 YALE L.J. 293 (1988) (rules shouldn’t encourage parental possessiveness and self-centeredness); Elizabeth S. Scott, Pluralism, Parental Preference, and Child Custody, 80 CALIF. L. REV. 615 (1992).

$21 \quad$ Elizabeth S. Scott \& Robert E. Emery, Gender Politics and Child Custody, NELLCO Legal Scholarship Repository, (Columbia University, 2011)(forthcoming 76 LAW \& CONT. PROBS. - (2014). 22 See, e.g., Hasday, supra note 18, at 825, 849 (2004); MiCHAEL GROSSBERG, GOVERNING THE HEARTH: LAW AND THE FAMILY IN NinETEENTH-CENTURY AMERICA 235 (1985); Judith T. Younger, Responsible Parents and Good Children, 14 LAW \& INEQ. 489,497 (1996).

23 Hasday, supra note 18 , at 849.

24 See, e.g., J.B. v. A.B., 242 S.E.2d 248 (W. Va. 1978); Krieger v. Krieger, 81 P.2d 1081, 1083 (Idaho 1938); Kirstakas v. Kirstakas, 286 A.2d 535, 528 (Md. App. 1972); Tuter v. Tuter, 120 S.W.2d 203, 205 (Mo. App 1938).

25 (1973). See also Richard Neely, The Primary Caretaker Rule: Child Custody and the Dynamics of Greed, 3 YALE L. \& PoL'Y REV. 168 (1984-85); Kennedy v. Kennedy, 376 N.W.2d 702 (Minn. 1985). The rule was also briefly adopted by statute in Minnesota, and criticized by Gary Crippen, Stumbling Beyond Best Interests of the Child: Reexamining Child Custody Standard-setting in the Wake of Minnesota's Four Year Experiment with the Primary Caretaker Preference, 75 MINN. L. REV. 427 (1990-1991). The phrase still appears as one of a number of factors in many statutes and in many legal decisions. See, e.g., Minn. Stat. 518.17 (Factor 3); Gianvito v. Gianvito, (2009 Pa. Super. 1008)(though not always determinative). 26 Discussions of the rule appear in Robert Cochran, The Search for Guidance in Determining the Best Interests of the Child at Divorce: Reconciling the Primary Caretaker and Joint Custody Preferences, 20 U. RICH. L. REV. 1, 11-12 (1985); Crippen, supra note 25.

27 See, e.g., Jed H. Abraham, Why Men Fight for Their Kids: How Bias in the System Puts Dads at a Disadvantage, 17 FAM. Advoc. 48 (1994); Steven J. Bahr et al., Trends in Child Custody Awards: Has the Removal of Maternal Preference Made a Difference? 28 FAM. L.Q. 247, 255 (1994). 
The "best interests" rule itself has also morphed into a more solid standard by the addition of various factors defining "best interests." ${ }^{28}$ A mild form of a default rule can also be seen in states' adoption of parenting guidelines. ${ }^{29}$

For a discussion of the problems of presumptions creating entitlements, see ANDREW I. SCHEPARD, CHILDREN, COURTS AND CUSTODY, INTERDISCIPLINARY MODELS FOR DIVORCING FAMILIES 166 (2004):

Furthermore, presumptions that guide custody decisions in contested cases create legal entitlements that may inadvertently influence the bargaining and trade-offs of divorce settlement negotiations. A presumption of equal physical custody, for example, generally favors men who have not taken care of their children on a day-to-day basis, whereas a presumption favoring primary caretakers and continuity of pre-divorce child care relationships generally favors women. Each can use a custody presumption in his or her favor as a bargaining chip to seek more favorable financial terms in a divorce settlement. Because of the custody presumption, the parent who it favors may receive more economic benefits than he or she would otherwise be entitled to. Custody presumptions can thus create an incentive for parents to confuse their personal economic interests with their children's emotional needs, compounding the difficulties parents already face in focusing on the children's best interests in the turbulence of divorce.

See also Scott \& Emery, supra note 21 (arguing that the best interest rule has persisted because the groups are in equipoise, and that "best interests" functions poorly not only because of discretion but also because mental health professionals are ill-equipped to deal with competing claims of domestic violence and parental alienation syndrome. For evidence of what judges determined to be unfounded claims of domestic violence, see Douglas W. Allen \& Margaret F. Brinig, Do Joint Parenting Laws Make Any Difference? 8 J. EMPIRICAL Legal StUdS. 304, 321 \& Table 6 (2011). See generally Linda C. Elrod \& Milfred D. Dale, Paradigm Shifts and Pendulum Swings in Child Custody: The Best Interests of Children in the Balance, 42 FAM. L.Q. 381, 395-96 (2008). One recent study finding no evidence of parental alienation (but some of children deciding themselves for their own reasons not to have contact, is the "Nuffield Report", Jane Fortin, Joan Hunt \& Lesley Scanlan, Taking a Longer View of Contact: The Perspectives of Young Adults Who Experienced Parental Separation in Their Youth, Nuffield Foundation, Final Report, November 2012, xviii [hereinafter Nuffield Report], available at http://www.nuffieldfoundation.org/recollections-contactissues-young-adults (last visited April 22, 2013)(398 adults 18-35 interviewed by telephone, with 50 whose parents separated after the law changed in 1989 and who had contact with the non-custodial parent, having face to face in-depth interviews).

$28 \quad$ Thus even traditional "best interests" statutes list a set of factors that judges may or may not take into consideration. For example, the Model Marriage and Divorce Act, Section 402, defines "best interests" to include "all relevant factors including (1) the wishes of the child's parent or parents as to his custody; (2) the wishes of the child as to his custodian; (3) the interaction and interrelationship of the child with his parent or parents, his siblings, and any other person who may significantly affect the child's best interest; (4) the child's adjustment to his home, school and community. And (5) The mental and physical health of all individuals involved. The court shall not consider conduct of a proposed custodian that does not affect this relationship to the child." MinN. STAT. ANN. 518.17 includes in addition to these "the child's primary caretaker," "the length of time the child has lived in a stable, satisfactory environment and the desirability of maintaining continuity," "the permanence as a family unit, of the existing or proposed custodial home," "the child's cultural background," and "the effect on the child of the actions of an abuser, if related to domestic abuse...that has occurred between the parents." The statute bears the same exclusion of custodial conduct and requires detailed findings on each of the factors and an explanation of how these led to the court's conclusion.

29 For Indiana's, see http://www.in.gov/judiciary/rules/parenting/. The Indiana Parenting Guidelines are designed to "represent the minimum recommended time a parent should have to maintain frequent, meaningful, and continuing contact with a child." Guidelines at 6 . By giving a minimum amount, this also places an upper boundary, or maximum amount, of time the other parent can have. This would be seem to meet one of Fennell's "overharvesting" concerns, Lee Anne Fennell, in Adjusting Alienability, 122 HARV. L. REV. 1404, 1429-34 (2009), though frequent transfers between parents could also tax the child either 
A variant of both "primary caretaker" and "joint custody," the replication rule, was advocated by the American Law Institute in $2000,{ }^{30}$ but has only taken statutory root in one state. West Virginia's experiment with the primary caretaker rule ended when the legislature adopted the "replication" standard in 2001. ${ }^{31}$ Part of a much larger framework of placing decisionmaking primarily upon the parents, Section 2.09 provides that in the case where they cannot agree, the judge will award custody to fit divorcing parents "in light of the caretaking functions each parent performed for the child before their separation," with "the amount of residential time that will allow the child to maintain a meaningful relationship with each parent." While in some families this would resemble the traditional mother-custody-with-frequent and-regular-visitation pattern, the ALI standard would also (and increasingly, these days ${ }^{32}$ ) allow for frequent, and sometimes equal, contact with both parents, if that is the way they parented before. ${ }^{33}$ The ALI replication rule also gives no incentive to divorce based on expectation of custody nor bargaining leverage that wasn't there already. ${ }^{34}$

Joint custody was popularized for a fairly brief time in the late 1980s in a few states, notably California ${ }^{35}$ and Wisconsin, ${ }^{36}$ but joint physical custody was opposed by feminists and advocates for victims of domestic violence ${ }^{37}$ as well as some academics who were concerned about the effect of continued mobility on children, especially infants. ${ }^{38}$ Since then, another round of joint custody presumptions has been fomented by father's rights groups, who have not been successful in courts on constitutional grounds ${ }^{39}$

because of the amount of time spent in transportation or in the confusion as the child transitions between homes and family systems.

$30 \quad$ ALI PRINCIPLES, supra note 9, at $\$ 2.07$ (2000). See also John S. Murray, Improving Parent and Child Relationships Within the Divorced Family: A Call for Legal Reform, 19 U. MICH. J.L. REF. 563 (1986)

31 W.VA.CODE ANN. §48-9-206 (MICHIE 2001). The test is sometimes called the "approximation rule."

32 ELLEN GALINSKY, KERSTIN AUMANN \& JAMES T. BOND. GENDER AND GENERATION AT WORK AND AT HOME. NEW YORK, NY: FAMILIES AND WORK INSTITUTE (2009); Suzanne Bianchi, Maternal Employment and Time with Children: Dramatic Change or Surprising Continuity, 37 DEMOGRAPHY 401, 411 (2000)(for working two-parent families, fathers do about a third of the child care).

33 A survey of Pima County residents supported equal custody awards in hypothetical situations where pre-separation parenting was equally shared. See Braver et al., supra note 11.

$34 \quad$ For empirical work examining the relationship between expectations of custody and filing for divorce, see Margaret F. Brinig \& Douglas W. Allen, “These Boots Are Made for Walking”: Why Most Divorce Filers Are Women, 2 AM. L. \& ECON. REV. 126 (2000), Douglas W. Allen \& Margaret F. Brinig, Child Support Guidelines: The Good, the Bad, and the Ugly, 45 FAM. L.Q. 135 (2011).

$35 \quad$ See Catherine R. Albiston \& Eleanor E. Maccoby, Does Joint Legal Custody Matter?, 2

STANFORD L. \& POL'Y REV. 167 (1990)(changing the custody standard did not make an appreciable difference in actual, as opposed to court ordered, custody and visitation patterns.)

$36 \quad$ See, e.g., Margaret F. Brinig \& Michael V. Alexeev, Trading at Divorce, Preferences, Legal Rules and Transaction Costs, 8 OHIO ST. J. ON DISP. RESOL. 279 (1993).

37 See, e.g., Margaret F. Brinig, Does Mediation Systematically Disadvantage Women?, 2 WM. \& MARY J. OF WOMEN \& L. 1 (1995), and sources cited therein.

38 See, e.g., Samatha Tornello et al., Overnight Custody Arrangements, Attachment, and Adjustment Among Very Young Children. 75 J. MARRIAGE \& FAM. 871 (2013).

39 See, e.g., Margaret F. Brinig, Does Parental Autonomy Require Equal Custody at Divorce?, 65

LA. L. REV. 1345 (2005). 
but have gained ground in some state legislatures, notably in Arkansas, ${ }^{40}$ Arizona, ${ }^{41}$ Iowa ${ }^{42}$ New Mexico ${ }^{43}$ and Wisconsin. ${ }^{44}$ For a time in the early 1980 s, and increasingly since the turn of the century, joint custody (meaning alternating or shared custody or parenting time) has been another option. ${ }^{45}$ Because both parents, at least in theory, win, ${ }^{46}$ and because judges need not make difficult custody determinations, joint custody presumptions have been seen as vindicating parental rights, forcing parents to cooperate in the reconstituted family, ${ }^{47}$ and ensuring children the two parent influence so many lack at parental dissolution. ${ }^{48}$ The joint custody rule — particularly in its strong form, the equal

$\begin{array}{ll}40 & \text { ARK. CODE } \$ 9-13-101(\mathrm{c})(2) . \\ 41 & \text { ARIZ. REV. STAT. } \$ 25-403.02 . \\ 42 & \text { IOWA CODE ANN. } \$ 541.41(1)(\mathrm{a}) \\ 43 & \text { N.M. STAT. } § 40-4-91 \\ 44 & \text { WIS. STAT. } \S 767.41 \\ 45 & \text { How often it is actually used, and remains viable for parents, is another matter. For a chart }\end{array}$ illustrating the incidence of joint custody internationally, see University of Oxford, Department of Social Policy and Intervention, Caring For Children After Parental Separation: Would Legislation For Shared Parenting Time Help Children? (May, 2011). at 4 \& Table 1 (3.1\% in the U.K. to $28 \%$ in Sweden). For some U.S. state experiences, see fn. 53-58, infra. There is a presumption since 2006 in Australia that the best interests of the child is to have equal shared parenting responsibility, under the Family Law Act § 61 DA and, that the court must consider whether if reasonably practicable and in the best interests of the child to spend equal time, or failing that, significant and substantial time, with each parent. Family Law Act $\S 65$ DAA (defined as time allowing each parent to be involved in the child's daily routine and significant events. Family Law Act $\$ 65$ DAA (3).

$46 \quad$ See, e.g., Brinig, Feminism and Child Custody Under Chapter Two of the American Law Institute's Principles of the Law of Family Dissolution, 8 DUKE J. GENDER L \& POL'Y 301, 314 (2001).

$47 \quad$ For some generally favorable consideration of the idea in principle, see Margaret F. Brinig \& F.H. Buckley, Joint Custody: Bonding and Monitoring Theories, 73 IND. L. J. 393 (1998). More recently, see ROBERT E. EMERY, RENEGOTIATING FAMILY RELATIONSHIPS: DIVORCE, CHILD CUSTODY, AND MEDIATION (2d ed. 2012).

$48 \quad$ See, e.g., Pruett \& DiFonzio, supra note 11, at 159:

Research has led to widespread agreement among professionals that children generally have improved prospects after separation and divorce when they have healthy, loving relationships with two parents before and after separation and divorce. Research has also soundly established that the multiple changes in home, school, neighborhood, and so on that often accompany separation and divorce are difficult for children and that continuity and consistency-especially in quality parenting and parent-child relationships - support child adaptation. In particular, studies have focused on the importance for children of their fathers staying involved after separation, as fathers are more likely than mothers to spend less time with or withdraw from their children after separation.

For a recently adopted favoring both parenting plans and joint custody, see ARIZ. REV. STAT. § 25-403.02 (effective Jan. 1, 2013)(“B. Consistent with the child's best interests ...the court shall adopt a parenting plan that provides for both parents to share legal decision-making regarding their child and that maximizes their respective parenting time.”) See also FLA. STAT. ANN. § 61.13 (c) (2010) (statute as a whole establishes a presumption of substantial time with each as being in child's best interests; section (3) establishes factors governing parenting plan); LA. STAT. ANN. § 9:335 (requires court to establish joint custody implementation order except for good cause show; provides that "to the extent it is feasible and in the best interest of the child, physical custody of the children should be shared equally"); 40-4-9.1 (establishes a presumption that joint custody is in the child's best interests but then sets forth factors and requires parenting plan; no specific time sharing arrangement required though time with each is to be "significant").

A recent attempt to enact a very strong presumption of joint custody, S.F. 1218, passed the legislature but was vetoed by Minnesota's governor. Another has reportedly been introduced in this year's session, as has a similar proposal in Michigan. H.B. 4120, see 
custody rule — has been a particular darling of interest groups concerned about the too real plight of noncustodial parents, especially fathers. ${ }^{49}$ As a "rights-based" approach, it has also gleaned support from some civil libertarians, ${ }^{50}$ and, early on, "sameness" feminists. ${ }^{51}$ On a slightly less exalted plain, because child support guidelines shift once a

http://achildsright.typepad.com/achildsright/2013/01/mi-2013-2014-equal-parenting-bill-hb-4120.html and http://parentalrightsequality.blogspot.com/2013/01/michigan-2013-14-hb-4120-equal.html. In 2005, an equal time provision was introduced but died in committee in California. AB 1307, Bill Analysis,

Assembly Comm. On Judiciary, May 3, 2005, at http://www.leginfo.ca.gov/cgibin/postquery?bill_number=ab_1307\&sess=0506\&house=B\&author=dymally. See also W. VA. SB 438 (2009), discussed in Alison Knezevich, Sweeping Child-Custody Changes Proposed, 3\16\09, wvgazette.com; N.Y. A03181 (2009) (requiring court to order joint custody unless contrary to child's interest). While Maine and Iowa, IOWA CODE § 541.41(1)(a) have very strong presumptions, at least Iowa's Supreme Court has decided that consistent with "best interests," the legislature could not have enacted a joint physical custody presumption. In re Marriage of Hansen, 733 N.W.2d 683, 697 (Iowa 2007). For discussion, se http://www.iowafathers.com/. The politics and public choice considerations for most of this legislation is discussed in Scott \&. Emery, supra note 21.

In Great Britain, an equal custody bill was also defeated. See Tim Shipman, Fathers Lose Bid for Equal Custody Rights after Review of Family Law, mailonline, Nov. 2, 2011; see generally Alexander Masardo, Managing shared residence in Britain and France: Questioning a default primary carer model. In, Social Policy REVIEW 21197 (Kirsten Rummery, Ian Greener \& Chris Holden,eds.2009). For research justifying the bill's defeat, see Nuffield Report, supra note 25, at xviii.

In Australia, the measure achieved more success with 2006 legislation including the introduction of a presumption in favor of "equal shared parental responsibility" (Family Law Act §61DA(1)), with a nexus between the application of the presumption and considerations in relation to time arrangements (Family Law Act §65DAA). The presumption may be rebutted by evidence satisfying a court that it would not be in a child's best interests for both parents to have equal shared parental responsibility (Family Law Act §61DA(4)), and it is not applicable where there are reasonable grounds to believe that a parent has engaged in child abuse or family violence (Family Law Act §61DA(2)). Where orders for shared parental responsibility are made pursuant to Family Law Act §61DA(1), the courts are obliged to consider whether making orders for children to spend equal or substantial and significant time with each parent, would be reasonably practicable and in the child's best interests (Family Law Act § 65DAA). For a discussion, see Ruth Weston, Lixia Qu, Matthew Gray, John De Maio, Rae Kaspiew, Lawrie Moloney and Kelly Hand, Shared Care Time: An Increasingly Common Arrangement, Australian Institute of Family Studies, Family Matters No. 88, 2011, available at http://www.aifs.gov.au/institute/pubs/fm2011/fm88/fm88f.html, For a discussion of the need to consult children, see PATRICK PARKINSON AND JUDY CASHMORE, THE VOICE OF A CHILD IN FAMILY LAW DISPUTES (2009) (suggesting that there are both pros and cons of involving children directly and that in any event they should not be understood to make the decision).

For a discussion of these and other Western European jurisdictions' custody rules, see PATRICK PARKINSON, FAMILY LAW AND THE INDISSOLUBILITY OF PARENTHOOD, 45-56 (2011).

$49 \quad$ See, e.g., Fathers and Dads for Equal Custody Rights, http://www.fathersrights.org/.

One interesting statistic is that shared custody families more often involve boys than girls. Sons are slightly more likely than daughters to be living in a shared parenting family. Heather Juby, Celine Bourdais, , \& Nicole Gratton, Sharing Roles, Sharing Custody, 67 J. MARRIAGE \& FAM., 157 (2005).; Ed Spruijt \& Vincent Duindam, (2010). Joint Physical Custody In The Netherlands And The Well Being Of Children. 51 J. Div. \& REMARRIAGE, 65, 72 \& Table 3 (2010)(19\% of the boys and 15\% of the girls lived in shared custody HOUSEHOLDS' 3561 Dutch children surveyed); Dutch children surveyed); Marygold S. Melli \& Patricia R. Brown, Exploring A New Family Form- The Shared Time Family, 22 INT'L J. L, POL'Y $\& 231,238 \&$ Table 1 (2008)(of 598 surveyed families, 35.7\% of the mother custody families had only girls, compared to $30.9 \%$ of the shared placement families).

$50 \quad$ See, e.g., Donald C. Hubin, Parental Rights and Due Process, 1 J. L. \& FAM. STUD. 123 (1999). For one such argument, see Edward Kruk, Arguments for an Equal Parental Responsibility Presumption in Contested Child Custody, 40 AM.J. FAMILY THERAPY 33, (2012) (British Columbian social worker).

$51 \quad$ See, e.g., the testimony for the Idaho joint custody bill, 1982 S.B. 1379, introduced by the only female state senator, Edith Miller Klein, with favorable testimony from a women's rights advocate. Klein 
child spends some amount of time (typically a quarter to a third) with each parent, wealthier noncustodial parents are particularly attracted to equal custody shares. ${ }^{52}$

While this is an empirical point, and one that might be fruitfully explored, it would be interesting to see whether the attempt by states to segregate the various categories proposed by Mnookin - saying that child support is fixed by guidelines, for example, or that nonpayment of child support has no effect on access to children (and vice-versa), are frustrated by many states' decision to allow variance from the guidelines once some threshold time with children is achieved. Some states (among them the large states of Florida, ${ }^{53}$ Illinois, ${ }^{54}$ Massachusetts, ${ }^{55}$ Pennsylvania, ${ }^{56}$ Texas $^{57}$ and Washington ${ }^{58}$ )

successfully sponsored a resolution to eliminate all sex discrimination in Idaho law. http://www.boiseartsandhistory.org/blog/2012/11/08/mrs-edith-miller-klein-an-idaho-senator/. She and her husband had no children. Legal Pioneer, Former State Senator Klein Dies At 83, Idaho SpokesmanReview Jan. 2, 1999.

$52 \quad$ See, e.g., Jessica Pearson \& Nancy Thoennes, Supporting Children After Divorce: The Influence of Custody on Support Levels and Payments, 22 FAM. L.Q. 319, 321 (1988); Jana B. Singer \& William L. Reynolds, A Dissent on Joint Custody, 47 MD. L. REV. 497, 517 (1988)(“'Legislation skewed toward awards of joint custody increases the ability of the parent requesting joint custody to engage in this type of extortion. David Chambers has noted that 'a parent who is not really interested in having joint custody may use the threat of demanding it as a tool to induce the other parent to make concessions on issues of property division and child support."')

53 FLA. STAT. $\S 61-30$. The statute provides in (1)(a) that "Notwithstanding the variance limitations of this section, the trier of fact shall order payment of child support which varies from the guideline amount as provided in paragraph (11)(b) whenever any of the children are required by court order or mediation agreement to spend a substantial amount of time with either parent. This requirement applies to any living arrangement, whether temporary or permanent." The state does have a shared custody presumption. Fla. Stat. $\S 61.13(2)(c)(2)(2009)$, but still requires a best interests determination by the court even if there is agreement. Sparks v. Sparks, Fla. Dist. Ct. App., No. 1D11-3327, 12/20/11.

54750 ILL. COMP. STAT. 5/505 (provides for specific percentages of supporting party's net income based on number of children, to be varied only if inappropriate after considering the best interests of the child in light of various relevant factors (not including shared custody). Illinois law contains no statutory presumption of equal parenting time even where the parents are awarded joint legal custody. Ill. Comp. Stat. 750 ILL. COMP STAT. § 5/602.1(d) ("Nothing within this section shall imply or presume that joint custody shall necessarily mean equal parenting time.")

55 MASS. GEN. LAWS ch, 208, $\S 28$ (allows for rebuttal of presumptive guideline amounts if unjust or inappropriate under the circumstances and written findings of the specific facts of the case justifying departure from the guidelines. Mass. Gen. Laws Ann. ch. 208, §31 provides that "physical custody shall be shared by the parents in such a way as to assure a child frequent and continued contact with both parents."

$56 \quad 23$ PA. CONS. STAT. ANN. § 4322 ("There shall be a rebuttable presumption, in any judicial or expedited process, that the amount of the award which would result from the application of such guideline is the correct amount of support to be awarded. A written finding or specific finding on the record that the application of the guideline would be unjust or inappropriate in a particular case shall be sufficient to rebut the presumption in that case, if based upon" "the reasonable needs of the child or spouse seeking support and the ability of the obligor to provide support, with primary emphasis on the net incomes and earning capacities of the parties, with allowable deviations for unusual needs, extraordinary expenses and other factors, such as the parties' assets, as warrant special attention." Since 2010, Pennsylvania's custody law provides that "it is public policy of this Commonwealth, when in the best interest of the child, to assure a reasonable and continuing contact of the child with both parents after a separation or dissolution of the marriage and the sharing of the rights and responsibilities of child rearing by both parents and continuing contact of the child or children with grandparents when a parent is deceased, divorced or separated." However, shared parenting is just one of the options listed in $23 \mathrm{~Pa}$. Cons. Stat. 5323. 
do not have an offset for shared parenting time. Others, such as Arizona, ${ }^{59}$ California, ${ }^{60}$ Michigan, ${ }^{61}$ Oregon $^{62}$ and Virginia, ${ }^{63}$ do allow for offset. What is the effect on the

57 TEX. FAM. CODE ANN. § 154.121 (Section 154.123 does allow, in (b), variance based on "(4) the amount of time of possession of and access to a child.") The state does presume that shared parenting is in the child's best interests. Tex. Fam. Code Ann. $§ 153.001$ (West), for the "public policy of this state" consists of "assur[ing] that children will have frequent and continuing contact with parents who have shown the ability to act in the best interest of the child; [] provid[ing] a safe, stable, and nonviolent environment for the child; and [] encourag[ing] parents to share in the rights and duties of raising their child after the parents have separated or dissolved their marriage."

58 WASH. REV. CODE $§ 26.19 .001$ includes in the legislative intent and finding "(3) Reducing the adversarial nature of the proceedings by increasing voluntary settlements as a result of the greater predictability achieved by a uniform statewide child support schedule."

The custody statute provides that "The court shall make residential provisions for each child which encourage each parent to maintain a loving, stable, and nurturing relationship with the child, consistent with the child's developmental level and the family's social and economic circumstances." WASH. REV. CODE $\S 26.09 .187(3)(a)$, but that " $[\mathrm{t}]$ he court may order that a child frequently alternate his or her residence between the households of the parents for brief and substantially equal intervals of time (joint physical custody) only if the court finds the following:

The parties have agreed to such provisions and the agreement was knowingly and voluntarily entered into; or

The parties have a satisfactory history of cooperation and shared performance of parenting functions; the parties are available to each other, especially in geographic proximity, to the extent necessary to ensure their ability to share performance of the parenting functions; and the provisions are in the best interests of the child." Rev. Code Wash. $\S 26.09 .187(3)$ (b)

A 2009 Washington State study found that " 46 percent of children of divorce, statewide, are ordered to spend a minimum of 35 percent parenting time with their biological fathers." Bill Harrington, Giving Parents Equal Parenting Time by Law, Seattle Times, Feb. 25, 2009, at http://seattletimes.com/html/opinion/2008786615 opinb26harrington.html.

$59 \quad$ ARIZ REV. STAT. § 25-320. Section (D)(8) provides that "The duration of parenting time and related expenses" shall be one of the criteria. While Schedule A to the child support guidelines subtracts some percentage from the amount otherwise owed for various levels of parenting days (computed in six hour increments) up to $48.6 \%$ (for 182 days), Schedule B, in effect when custody is shared equally, subtracts the lower earning parent's total amount due from the higher, and then divides the difference in two. If \$2000 per month is owed, and only one parent has any earnings at all, this means the parent who would otherwise pay $\$ 2000$ only pays $\$ 1000$. Thus the biggest disadvantage is to lower earning parents when incomes are the most disparate. Further, while many states multiply the amount owed in order to recognize the duplicate fixed expenses when children are living in two households, see Allen \& Brinig, supra note 57, Arizona uses the same total child support duty whether all overnights are with one parent or whether $50 \%$ of the time is spent in each parent's household. This means that the baseline amount is lower.

Arizona recently adopted a new parenting time statute. ARIZ. REV. STAT. § 25-403.02 (2013), providing that (B) "Consistent with the child's best interests ..., the court shall adopt a parenting plan that provides for both parents to share legal decision-making regarding their child and that maximizes their respective parenting time." There is no explicit preference for joint custody, though the new statute does provide for maximum time with each parent.

60 CAL. FAM. CODE $\S 4503$ provides in (c) "The guideline takes into account each parent's actual income and level of responsibility for the children." Section 4055 provides for the guideline, and in (3) provides for a multiplier that is the "approximate percentage of time that the high earner has or will have primary physical responsibility for the children compared to the other parent." CAL. FAM. CODE $§ 3020$ (b) provides that "The Legislature finds and declares that it is the public policy of this state to assure that children have frequent and continuing contact with both parents after the parents have separated or dissolved their marriage, or ended their relationship, and to encourage parents to share the rights and responsibilities of child rearing in order to effect this policy, except where the contact would not be in the best interest of the child, as provided in Section 3011. "Section (a) provides that safety of the child is the 
percentage of custody awarded to or bargained for by each parent? Lee Fennell, writing in the property context, ${ }^{64}$ suggests that sometimes bargaining allows inalienability rules to become permeable. Even if they are not, the economically stronger party can exert leverage along other, permissible fronts such as child support in excess of the standard, or, as Mary Ann Glendon suggests, delay in or cost of, the proceedings. ${ }^{65}$

court's primary concern. Section (c) provides "Where the policies set forth in subdivisions (a) and (b) of this section are in conflict, any court's order regarding physical or legal custody or visitation shall be made in a manner that ensures the health, safety, and welfare of the child and the safety of all family members."

612013 Michigan Child Support Formula Manual. Sec. 3.03 allows for adjustment based on parental time since "Presuming that as parents spend more time with their children they will directly contribute a greater share of the children's expenses, a base support obligation needs to offset some of the costs and savings associated with time spent with each parents." The (complicated) formula takes into account the approximate annual number of overnights spent with each parents as well as the two parents' base support obligation. Available at http://courts.mi.gov/Administration/SCAO/Resources/Documents/Publications/Manuals/focb/2013MCSF.p df.

The current statute, MICH. COMP. LAWS $§ 722.23$ provides simply for a list of factors. The legislature is currently considering a presumptive joint custody statute.

62 ORE. REV. STAT. §§ 137-050-0700 et seq. The amount of time each parent spends with their children is factored into the calculation. A calculator is available following the links at http://www.oregonchildsupport.gov/calculator/index.shtml. 107.101:

While Oregon law is complex and requires parenting plans, joint custody is preferred under

It is the policy of this state to:(1) Assure minor children of frequent and continuing contact with parents who have shown the ability to act in the best interests of the child;(2) Encourage such parents to share in the rights and responsibilities of raising their children after the parents have separated or dissolved their marriage;(3) Encourage parents to develop their own parenting plan with the assistance of legal and mediation professionals, if necessary;(4) Grant parents and courts the widest discretion in developing a parenting plan; and(5) Consider the best interests of the child and the safety of the parties in developing a parenting plan.

More than a third of Oregon divorces in 2002 involved joint custody. Allen \& Brinig, supra note 25.

63 VA. CODE ANN. § 20-108.2 (G)(3)@, provides for different calculations when a party has custody or visitation of a child or children for more than 90 days of the year. Custody shares are determined by dividing the number of days by 365 . Shared support need means the presumptive guideline amount of needed support for the shared child(ren) using the schedule for the combined gross income of the parents and the number of shared children, multiplied by 1.4. The mother would then pay the shared support need times the father's custody share plus the health care and child care paid by mother times her income share. The two may be offset by subtracting the smaller from the larger.

Section 20-108.1 provides that the guideline amounts may be rebutted by (2) arrangements regarding custody of the children, including the cost of visitation travel.

Va. Code Ann. § 20-124.2 provides:

B. In determining custody, the court shall give primary consideration to the best interests of the child. The court shall assure minor children of frequent and continuing contact with both parents, when appropriate, and encourage parents to share in the responsibilities of rearing their children. As between the parents, there shall be no presumption or inference of law in favor of either. The court shall give due regard to the primacy of the parent-child relationship but may upon a showing by clear and convincing evidence that the best interest of the child would be served thereby award custody or visitation to any other person with a legitimate interest. The court may award joint custody or sole custody.

64 Fennell, supra note 29. See also Daniel B. Kelly, Strategic Spillovers, 111 Colum. Law Rev.

1641 (2011) (Threatening, while never intending, an action involving property may cause the other party or parties to act in a way advantaging the strategist).

$65 \quad$ Mary Ann Glendon, Fixed Rules and Discretion in Contemporary Family Law and Succession

Law, 60 TUL. L. REV. 1165, 1170 (1986), notes that "the greatest damage from the lack of clarity in the law 
As one might predict from Mnookin and Kornhauser's stress on bargaining, ${ }^{66}$ at the same time as these substantive debates over standards, a growing movement toward alternative dispute resolution for dispute settlement has both engaged and alarmed the major players. ${ }^{67}$ While the ALI's "replication" parenting time standard has convinced a limited audience, its reliance on parenting plans has, in some form, surfaced in virtually every U.S. jurisdiction. ${ }^{68}$ Many states mandate mediation in disputed custody cases, and the remainder allow it when the parents wish it or allow judges to refer even recalcitrant parents to it. ${ }^{69}$ In the late 1980 s to the mid-1990s, a feminist-led objection to the informality and face-to-face nature of mediation when there was domestic violence ${ }^{70}$ or significant power disparities crystalized in exceptions to mandatory — or any other form of-mediation. ${ }^{71}$ Still more recently, both judges and other professionals ${ }^{72}$ have noted that any kind of default rule disadvantages the children who need the most help, those

occurs in those divorces, the overwhelming majority, that are settled by the parties before trial...To the extent that it is impossible to get or give sound advice on how a court is likely to resolve a given issueand a large measure of discretion means exactly that - the economically stronger party gains negotiating leverage from the superior ability to prolong negotiation, to engage in expensive pretrial discovery, and to use preliminary court appearances for harassment.")

66 Mnookin \& Kornhauser, supra note 12.

67 See, e.g., Trina R. Grillo, The Mediation Alternative: Process Dangers for Women, 100 YALE L.J. 1545, 1595-96 (1991); Laurie Woods, Mediation: A Backlash to Women's Progress on Family Law Issues, 119 Clearinghouse Rev. 431, 435 (1985); Penelope E. Bryan, Killing Us Softly: Divorce Mediation and the Politics of Power, 40 Buff. L. Rev. 441 (1992); Martha Shaffer, Divorce Mediation: A Feminist Perspective, 46 U. TORONTO FAC. L. ReV. 162 (1988); Scott Altman, Should Child Custody Rules Be Fair?, 35 U.,LouisviLle J. FAM. L. 325, 353 (1996); Margaret F. Brinig, Does Mediation Systematically Disadvantage Women, 2 WM. \& MARY J. WOMEN \& L. 1 (1995); but see Joan Kelly, Mediated and Adversarial Divorces: Respondents' Perceptions of Their Processes and Outcomes, 24 Mediation Q. 71, 78 (1989).

68 ALI PRINCIPLES, supra note 9, at $\S 2.05$ (2002)(“The parenting plan is a core concept of this

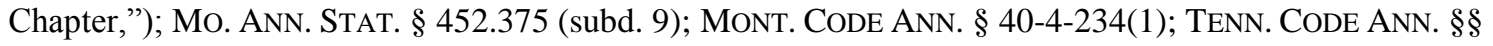
336-6-401 et seq.; WASH. REV. CODE ANN. § 26.09, discussed in Jane W. Ellis, Plans, Protections, and Professional Intervention: Innovations in Divorce Custody Reform and the Role of Legal Professionals, 24 U. MICH. J.L. REF. 65 (1990).

69 One early defense of mediation is Andrew Schepard, Taking Children Seriously, Promoting Cooperative Custody After Divorce, 64 TEX. L. REV. 687 (1985). A collection of the mediation statutes can be seen in Reporter's Notes to $\S 2.07$, ALI PRINCIPLES, supra note 9, at 171-176 (2000), and online updates, $70 \quad$ For one elaborate set of procedures designed to minimize harm in families with violence, see Department of Justice, Canada, Making appropriate parenting arrangements in family violence cases: applying the literature to identify promising practices, available at http://www.justice.gc.ca/eng/pi/fcyfea/lib-bib/rep-rap/2006/2005_3/sum-som.html.

71 See sources cited in note 67, supra. It also causes exceptions to parenting guidelines. See Indiana Court Rules, Indiana Parenting Time Guidelines, Scope, § 1, at 1-2 (2008)(“However, they are not applicable to situations involving family violence, substance abuse, risk of flight with a child, or any other circumstances the court reasonably believes endanger the child's physical health or safety, or significantly impair the child's emotional development.").

72 In the AFCC "think tank," the non-judicial group included custody evaluators (neutrals appointed by courts to determine "best interests), lawyers representing victims of domestic violence, especially the indigent, lawyers who handle high profile custody disputes involving wealthy clients, as well as the mental health professionals who testify on behalf of mothers or fathers in custody litigation. Of course all these players, and by definition the judges hearing custody cases, deal with the small percentage who end up in litigation. 
with parents in conflicted custody proceedings, particularly those with parents of low- or modest income. $^{73}$

I have mentioned Mnookin and Kornhauser. At roughly the same time as divorces reached $50 \%$ of first marriages, two scholars, Robert Mnookin and Lewis Kornhauser, published a path-breaking article in the Yale Law Journal. ${ }^{74}$ "Bargaining in the Shadow of the Law: The Case of Divorce" immediately became featured reading in dispute resolution, family law, and, to an only slightly lesser extent, law and economics. For purposes of this paper, the important points were, first, that legal rules set an endowment (or starting) point for bargaining at divorce, bargaining that in its essence is between money (property, alimony and child support) and time with children (custody and visitation). ${ }^{75}$ Secondly, they maintained that women were disadvantaged by a movement toward gender-neutral "best interests of the child" rules ${ }^{76}$ because they would trade financial assets to secure what they really valued, time with their children. ${ }^{77}$ Men might take advantage of the rules to behave strategically, threatening to ask for custody when in fact they didn't really want it (or not as much time as they'd asked for). ${ }^{78}$

For the past thirty-five years, this bargaining paradigm has dominated the thinking of scholars who have looked systematically at what was happening during the divorce process. It has influenced the procedures favored for custody disputes, particularly because it brought to common understanding the statistic that about $90 \%$ were settled before trial, ${ }^{79}$ a percentage that has stood up through many empirical tests. ${ }^{80}$ It was part

73 This was one of the themes at the AFCC think tank. See, e.g., Mary Jean Dolan \& Daniel J. Hyman, An Empirical Critique of the ALI Approximation Rule for Child Custody Disputes, presented at the $5^{\text {th }}$ Annual Emerging Family Law Scholars and Teachers Conference, Fordham Law School, May 21, 2012; Elrod \& Dale, supra note 27, at 384 (2008)("High conflict parents keep their children and themselves in perpetual turmoil, consume an extraordinary amount of court services, and deplete their own personal and financial resources. Secondly, judges find themselves ill prepared to make future predictions about parents and their children.”); Pamela S. Rudolph, Attachment in Child Custody: An Additive Factor, Not a Determinative One, 46 Fam. L.Q. 1 (2012).

$74 \quad$ Mnookin \& Kornhauser, supra note 12. The divorce rate peaked in 1980-81.

75 Mnookin \& Kornhauser, supra note 12, at 959-60.

$76 \quad I d$. at 978-79. At the time Mnookin and Kornhauser wrote, many states still had maternal preference rules, especially for children of "tender years."

77 I will note that other than the writing of Richard Neely who made claims from his own practice, no study has found pervasive evidence that such trading did or does go on. Garska v. McCoy, 278 S.E.2d 357 (W. Va. 1981); Neely, supra note 23, at 177-78;Elster, supra note 2, at 5; Jerry McCant, The Cultural Contradiction of Fathers as Nonparents, 21 FAM. L.Q. 127, 137 (1987); Elizabeth Scott \& Andre Derdeyn, Rethinking Joint Custody, 45 OHIO ST. L.J. 455 (1984), Martha Fineman, Dominant Discourse, Professional Language and Legal Change in Child Custody Decisionmaking, 161 HARV. L. REV. 727, 76061 (1988); Katharine T. Bartlett, Child Custody in the $21^{\text {st }}$ Century: How the American Law Institute Proposes to Achieve Predictability and Still Protect the Child's Best Interests, 35 WILLIAMETTE L. REV. 467, 470 (1999), all assume trading of custody time for money takes place. Studies finding no evidence of trades include ELEANOR MACCOBY \& ROBERT MNOOKIN, DIVIDING THE CHILD 100-03 (1992) (about 10\% of fathers and $7 \%$ of mothers asked for more physical custody than they actually wanted, but there was no indication that this was to extract money); Robert Weiss and Robert Willis, Transfers Among Divorced Couples: Evidence and Interpretation, 11 J. LAB. ECON. 629 (1993); Brinig \& Aleeev, supra note 34.

78 See Mnookin \& Kornhauser, supra note 12, at 968-71, 972-73.

$79 I d$. at $955 \&$ n.23. For more recent affirmations, see SANFORD BRAVER \& MARY O'CONNELL, Divorced Dads: SHATtering THE MYTHS 1998; T.K. Logan et al., Divorce, Custody, and Spousal 
of the thinking behind separating the custody portion of dissolutions involving children from equitable distribution of property, alimony, and child support. While the timing may just be fortuitous, it is possible that "Bargaining in the Shadow" played a role in regularizing child support guidelines (thus removing child support to some extent from the bargaining table). ${ }^{81}$ The federally mandated and therefore ubiquitous child support guidelines, most often tie support obligations not only to parental income but also to the time spent with the child. ${ }^{82}$

What I'd like to address here is the role played by Mnookin and Kornhauser's central arguments about the law's setting an endowment point, one in which the uncertainty of the gender-neutral "best interests" would disfavor women. To flesh out the logic, we need at least one other step. This point was set not by academics or legislatures, but by the Supreme Court, ruling in a case about voluntary commitment of children for inpatient mental health treatment, a case called Parham v. J.R. ${ }^{83}$ The essential part of the Court's reasoning, from my perspective, is that "the law's concept of the family rests on a presumption that parents possess what a child lacks in maturity, experience and capacity for judgment" for making difficult decisions. "More important, historically it has recognized that natural bonds of affection lead parents to act in the best interests of their children." 84 In other words, parents are necessary and able to voice their children's best interests.

Violence: A Random Sample of Circuit Court Docket Records, 18 J. FAM. VIOLENCE 269 (2003) (Between 78 and $92 \%$ settled)

80 See, e.g., Braver, \& O'Connell, supra note 79 (2-10\% fail to reach settlement); Marygold Melli, Harold Erlanger \& Elizabeth Chambliss, The Process of Negotiation: An Exploratory Investigation in the Context of No-Fault Divorce, 40 RuTG. L. REV. 1133, 1142 (1988); Brinig \& Alexeev, supra note 36. See also Joan Hunt \& Caridwen Roberts, Child Contact with the Non-Resident Parents, 3 Family Policy Briefing 1, Department of Social Policy and Social Work, University of Oxford, 2004 (10\%) available at http://www.spig.clara.net/reports/hunt.pdf (last visited May 23, 2013); House of Representatives, Standing Committee on Families and Community Affairs, Every Picture Tells a Story Report of the Inquiry into Child Custody Arrangements in the Event of Family Separation 7 \& Fig. 1.1 (Parliament of Australia, 2003) (6-7\% actually produce a court judgment), available at http://www.aph.gov.au/Parliamentary_Business/Committees/House_of_Representatives_Committees?url=f ca/childcustody/report.htm (last visited May 23, 2013).

$81 \quad$ These have been mandated by Congress as part of Title IV of the Social Security Act since the late 1980s. Family Support Act of 1988, P.L. 100-485, 102 Stat. 2343 (codified throughout 42 U,S.C.); see, e.g., Linda D. Elrod \& Robert G. Spector, A Review of the Year in Family Law 2007-2008: Federalization and Nationalization Continue, 42 FAM. L.Q. 713, 759-60 \& Chart 3 (2009). For a discussion on the effect of various types of guidelines on divorce rates, with examples, see Allen \& Brinig, supra note 34 . For a discussion in general of the purposes of child support, see Marsha Garrison, An Evaluation of Two Models of Parental Obligation, 86 CAL. L. REV. 41 (1998).

82 Parenting time deductions sometimes begin after a certain threshold number of days or overnights is reached. Sometimes, as in Arizona, the deductions begin slowly, with as few as three days spent with the parent with less custodial time, increasing to $50 \%$ of the total amount computed in equal time situations. In some states, and Canada, the total amount due is increased by a multiplier (typically $40 \%$ is added to the original amount) in shared parenting situations before deductions are made, and in a few, only costs that vary with additional time are counted.

83442 U.S. 584 (1979). For my own work questioning whether parents are capable of making difficult choices at divorce or when the other parent dies, see Margaret F. Brinig, Troxel and The Limits of Community, 32 RUTG. L.J. 733 (2001).

$84 \quad 442$ U.S. at 602 . Note that this is in contradiction to the focus in other jurisdictions, begun with the UN Convention on the Rights of the Child Art. 12(2), which specifies that the child's voice must be 
Scott and Emery have looked at what seems to be a stalemate in the legislative action in terms of gender politics. Another possibility here, which we will consider again in the empirical section of this paper, is to consider the various goals that can be met with each kind of interpretation of "best interests." The three most important goals seem to be maintenance of stability and continuity, promotion of strong and meaningful relationships with both parents, and minimizing the child's exposure to violence and conflict. ${ }^{85}$ What is less clear is which goal is most important, whether any of the three trumps the other two, and whether a statutory presumption or something like parenting guidelines would best aid judges in handling contested cases as well as parents bargaining "in the shadow of the law." 86

The best available studies (long term, using large and representative samples, and from around the world), show that children are generally disadvantaged by their parents' divorce. ${ }^{87}$ Over the short term this is particularly acute, and can be seen in adjustment problems, financial difficulties, and distraction on the part of parents. Over the longer term, most children (probably in the $70 \%$ range), are quite resilient. ${ }^{88}$ Nonetheless children of divorce tend to delay marriage longer, marry less often, and divorce more frequently than children of intact families. ${ }^{89}$

Similarly, it is quite well demonstrated that some dissolving families experience domestic violence either before parents separate or on a continuing basis. ${ }^{90}$ The

heard in any jurisdicial and administrative proceeding affecting the child, either directly or through a representative or an appropriate body. For example, in Great Britain, the Children Act of 1987 and the Australian Family Law Reform Act of 1995 both give the child the rights and parents responsibilities. The parental rights perspective is criticized, inter alia, in Linda Henry Elrod, Epilogue: of Families, Federalism and a Quest for Policy, 39 FAM. L.Q. 843, 846 (1999); David Meyer, Constitutionalization of Family Law, 42 FAM. L.Q. 529 (2008).

$85 \quad$ For an early suggestion that conflict was important to avoid, see Elster, supra note 2.

$86 \quad$ Mnookin \& Kornhauser, supra note 12. See also Austin Sarat \& Wiliam L.F. Felstiner, Law and Strategy in the Divorce Lawyer's Office 20 L. \& Soc. REV. 93, 113 (1986), suggesting that most divorce lawyers try to get their clients to settle the full range of issues in the case rather than contest them.

87 See, e.g., Paul R. Amato, The Impact of Family Formation Change on the Cognitive, Social and Emotional Well-Being of the Next Generation, in 15 THE FUTURE OF CHILDREN: MARRIAGE AND CHILD WELLBEING 75, 77 (2005)(more behavioral problems, more symptoms of psychological maladjustment, lower academic achievement, more social difficulties, and poorer self-concepts). See also sources cited in P. PARKINSON \& J. CASHMORE, supra note 48 , at $1 \&$ n. 4 .

88 See, E. MAVIS Hetherington, For BetTER OR For Worse: Divorce ReCONSIDERED (2003); JUdith S., WALLERSTEIN ET AL., THE UNEXPECTED LEGACY: THE UNEXPECTED LEGACY OF DIVORCE: A 25 Year Landmark Study (2000) and PaUl R. Amato \& Alan Booth, A GENERATION AT RisK: Growing UP IN AN ERA OF FAMILY UPHEAVAL (1997).

89 See, e.g., Margaret F. Brinig \& Steven L. Nock, 'I Only Want Trust': Norms, Trust and Autonomy, 32 JouRNAL OF SOCIO-ECONOMICS 471 (2003); Marriage and Divorce in the United States, see generally Casey E. Copen et al., First Marriages in the United States: Data From the 2006-2010 National Survey of Family Growth, 49 National Health Statistics Reports, Mar. 22, 2012 (likelihood of divorcing, page 7; marrying page $12 \&$ Table 1 ; marrying older at $14 \&$ Table 3 , all based on presence or absence of both parents in household at age 14).

${ }^{90}$ See Shannon Catalino, Intimate Partner Violence, 1993-2010, Department of Justice, Bureau of Justice Statistics Fact Sheet (Nov.27, 2012), available at http://bjs.ojp.usdoj.gov/content/pub/pdf/ipv9310.pdf; 
proportion is disputed, but seems to be higher among those who never married than those who do. ${ }^{91}$ When children are exposed to violence (either between their parents or directed at themselves), no one doubts that they are harmed. ${ }^{92}$ Psychologists and sociologists write that families with a high degree of visible conflict are those in which children might even do better if their parents divorce than if the parents stay together. ${ }^{93}$

Along the same lines, some parents (how many is contested) are not fit to be regular caretakers for children, usually because they are involved with substance abuse, abuse of children or mental illness. ${ }^{94}$ (Some might be institutionalized in a variety of settings.) However, the vast majority are fit to be custodians.

(The data were developed from the Bureau of Justice Statistics' (BJS) National Crime Victimization Survey (NCVS), which annually collects information on nonfatal victimizations reported and not reported to the police against persons age 12 or older from a nationally representative sample of U.S. households. The report shows a declining rate from 1994 to 2010, from 9.8 per 1,000 persons age 12 or older to 3.6 per 1000. Females living in households comprised of one female adult with children experienced intimate partner violence at a rate more than 10 times higher than households with married adults with children. Id. at $2 \&$ Table 1.) Linda Girdner, Custody Mediation in the United States: Empowerment or Social Control? 3 CAN. J. WOMEN \& L. 134, 138 \& n.19 (1989)(reporting that a Canadian study shows physical violence given as reason for marital separation by 50-75\% of women); DEMIE KURZ, FOR RICHER, FOR POORER: FOR RICHER, FOR POORER: MOTHERS CONFRONT DIVORCE (1995)(about 30\%); Allen \& Brinig, supra note 27, at313 \& Table 1 (2011) (.26 (before 1997) to .21 (1998-2002) of random selection of divorce cases in Oregon involving children alleged domestic violence).

91 See, e.g., Amanda Berger et al., Relationship Violence Among Young Adult Couples, Child Trends Research Brief 2012-14 (2101), available at http://www.childtrends.org/Files/Child_Trends2012_06_01_RB_CoupleViolence.pdf (highest level among cohabiting couples, lowest among married couples, counting any type of violence and surveying both partners, $45 \%$ of married couples and $52 \%$ of cohabiting couples experienced violence; for those resulting in injury, $8 \%$ of married couples and $15 \%$ of cohabiting). This seems to be true in Spain and Great Britain as well.

92 See, e.g., АMATO \& BоOTH, supra note 88 (suggesting that children are only better off if their parents had a highly conflictual marriage before divorce, a case that occurs only about $30 \%$ of the time); and, more recently, E. MARK CUMMINGS \& PATRICK T. DAVIES, MARITAL CONFLICT AND CHILDREN: AN Emotional SECURITY PersPeCtive vii-viii (2010); Rena Repetti, Shelley E. Taylor \& Theresa E. Seeman, Risky families: Family \& Social Environments and the Mental and Physical Health of Offspring, 128 PSYCH. BULL. 330 (2002); ROBERT E. EMERY, RENEGOTIATING FAMILY RELATIONSHIPS 100 (2012) ("Hundreds of studies show that parental conflict is toxic for children in divorce"); E. Mark Cummings, Christine Merrilees \& Melissa Ward George, Fathers, Marriages, And Families: Revisiting And Updating The Framework For Fathering In Family Context, in THE Role Of The FATHER In CHILD Development 154 (5th ed., Michael E. Lamb, ed. 2010). See also Nuffield Report, supra note 27, at xii, xiii (ongoing conflict leads to poor relationships with parents in adulthood, as does absence of non-residential parent's emotional investment in the child's life).

93 For some examples, See Paul Amato \& Alan Booth, A Prospective Study of Parental Divorce and Parent-Child Relationships, 58 J. MARR \& FAM. 356 (1996); Susan Jekielek, Parental Conflict, Marital Disruption and Children's Emotional Well-Being, 76 Social ForCES 905 (1998); Donna Morrison \& Mary Jo Coiro, Parental Conflict and Marital Disruption: Do Children Benefit When High-Conflict Marriages are Dissolved, 61 J. MARRIAGE \& FAMILY 626 (1999); Alan Booth \& Paul Amato, Parental Pre-Divorce Relations and Offspring Post-Divorce Well-Being, 62 J. MARRIAGE \& FAMILY 197, 210 (2001).

94 One study indicates that this number is between 8 and 15\% than JANET JOHNSTON, VIVIENNE

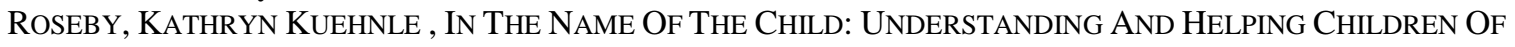
CONFliCted AND Violent DivorCE. New York: Springer. 2009. See Linda Neilson, Shared residential custody: Review of the Research, AM. J. FAM. L. 4 (January, 2013). 
There is no dispute over the fact that there are tremendous costs involved in litigated custody disputes. ${ }^{95}$ These costs can be seen in court time (and resources), ${ }^{96}$ the cost of the conflict to the child, the costs to each parent (financially, emotionally and socially), ${ }^{97}$ and the costs of their continuing to have to deal with each other in nonpositive ways, especially in cases involving domestic violence. ${ }^{98}$ As we have seen, there are also costs of uncertainty in deciding what's best for children.

Further, and not surprisingly, parents are enormously invested in their children. It may be slightly less obvious that loss of custody involves real harm (not just pretended or imagined harm) to them. ${ }^{99}$ As two-parent families with loving parents are best for children (biological or adoptive), continuing relationships with two nurturing parents (biological or adoptive) who no longer live together is typically the second-best solution. $^{100}$

At this juncture in time, professionals contest more than just percentages of time that should be allocated to each parent. Some claim that "relationship" equals "parenting time"101 and, "nurturing" necessarily involves overnight stays. Some claim that the

95 "Tragically, a small, but significant, number of parents engage in a type of guerilla warfare, litigating repeatedly, clogging courts and harming their children.” Elrod \& Dale, supra note 27, at 388

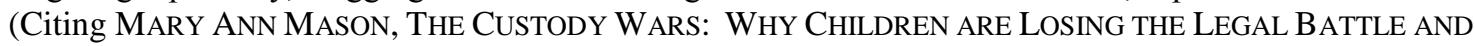
WhAT We CAN Do ABOUT IT (1999). The article concludes that "if it does not reduce conflict, it will not be in the best interests of children.” Id. at 418.; E. MACCOBY \& R. MNOOKIN, supra note 78, at 100, 159 (1992); Constance Ahrons, The Good Divorce 56 (1994); JANET R. JoHNSTON \& VIVIENNE Roseby, IN THE NAME OF THE ChILD: A DEVELOPMENTAL APPROACH To UNDERSTANDING AND HELPING CHILDREN 4 (1977).

96 See, e.g., Kyle Pruett \& Marsha Kline Pruett, Eds., ChILd AND AdOLESCENT Psychiatric CLINICS OF NORTH AMERICA: CHILD CUSTODY (1998). Experts will most clearly be needed when there is strategic behavior. There have been critics of their over-use in the past, that they have just increased the costs and given judges an excuse to do whatever they'd like anyway, that they can offer little because so much is contested or the research weak, and so forth.

$97 \quad$ Many of these costs are enumerated in Mnookin \& Kornhauser, supra note 12.

98 See, e.g., Merle H. Weimer, Domestic Violence and Custody: Importing The American Law Institute's Principles of the Law of Family Dissolution Into Oregon Law, 35 WILLIAMETTE L. ReV. 643, 645 (1998)(noting the attention paid to domestic violence in what was then a draft). More recently, see, e.g., Katherine M. Reihing, Protecting Victims of Domestic Violence and Their Children After Divorce: The American Law Institute's Model, 37 FAM. \& CONCILIATION CTS. ReV. 393, 398 (1999); Jennifer L. Hardesty and Lawrence H. Ganong, How Women Make Custody Decisions and Manage Co-Parenting with Abusive Former Husbands,23 J. SOC. \& PERSONAL RELATIONSHIPS 543 (2006). http://www.childtrends.org/Files/Child_Trends-2012_06_01_RB_CoupleViolence.pdf 99 Brinig \& Nock, supra note 84 (noncustodial fathers, holding constant all available other factors, have a real and significant increase in depressive symptoms following a custody order giving it to the mother).

$100 \quad$ See, e.g., "This paper starts from the viewpoint that evidence fully supports the benefit to children of having a meaningful relationship with both parents after separation." University of Oxford, Department of Social Policy and Intervention, Caring for children after parental separation: would legislation for shared parenting time help children? (May, 2011). See also Nuffield Report, supra note 27, at xii.

$101 \quad$ See, e.g., William B. Fabricius, Karina R. Sokol, Priscila Diaz \& Sanford L. Braver, Parenting Time, Parent Conflict, Parent-Child Relationships, and Children's Physical Health, in PARENTING Plan EVALUATIONS: APPLIED RESEARCH FOR THE FAMILY COURT 188, 193-94 (K. Juehnle \& L. Drozl, eds. 2012) (claiming that time is a necessary agreement for cultivating meaningful relationships); contra Paul R. Amato, \& Joan G. Gilbreth, Non-Resident Fathers And Children's Wellbeing: A Meta-Analysis, $61 \mathrm{~J}$. 
confusion caused by moving between two households outweighs the benefit, at least for some. ${ }^{102}$ There is debate about whether the "continuing relationship with two nurturing parents" trumps or is trumped by the child's need for continuity and stability. ${ }^{103}$ Experts do not agree whether exceptions to alternating custody need to be made when it's impracticable (say, for a nursing or infant child, ${ }^{104}$ or one with disabilities, or when a parent is in the armed forces, or lives too far away, or both are poor). ${ }^{105}$

Examining the various perspectives in turn, we come first to the child, who is the center of dispute between (we will assume) fit and loving parents, will be advantaged by the complementarity of the two parents involved, ${ }^{106}$ as well as by the continuity and

MARRIAGE \& FAM. 557 (1999), who review 63 studies on parent-child contact and children's well-being finding that the quality of contact is more important than the frequency of contact. Good outcomes for children were more likely when non-resident fathers had positive relationships with their children and had an 'active parenting' approach, including both warmth and setting boundaries. See also Brinig, supra note 27 (finding that overnights not statistically related to wellbeing, but "closeness" to non-custodial father was); Nuffield Report, supra note 25, at xii-xiii (overnights not strongly associated with positive experiences of closeness); those with more frequent contact had very close pre-separation relationships, but overnights not a significant factor). No blueprint works for all or even a majority of cases, $i d$. at xiii-xiv.

102 See, e.g., Juliana M. Sobowlewski \& Paul R. Amato, Parents' Discord and Divorce, Parent-Child Relationships and Subjective Well-Being in Early Adulthood: Is Feeling Close to Two Parents Always Better than Feeling Close to One?,85 SOCIAL FORCES 1105, 1118 (2007).

103 See, e.g., Pruett and DiFonzio, supra note 11, at 158 (1). One common place for this debate to play out is in "move away" cases. In the move-away context, see the rule enunciated in a California case: "Once the trial court has entered a final or permanent custody order reflecting that a particular custodial arrangement is in the best interest of the child, "the paramount need for continuity and stability in custody arrangements - and the harm that may result from disruption of established patterns of care and emotional bonds with the primary caretaker - weigh heavily in favor of maintaining" that custody arrangement. (Burgess, supra, 13 Cal. 4th 25, at 32-33, 51 Cal.Rptr.2d 444, 913 P.2d 473.) In re Marriage of Brown \& Yana, 37 Cal. 4th 947, 956, 127 P.3d 28, 32 (2006) notes that parental happiness is a lesser concern than either of the other two.

104 For arguments that shared parenting of infants involving overnight stays is not appropriate, see Jennifer McIntosh, Bruce Smyth, Margaret Kelaher \& Yvonne Wells, Post separation parenting arrangements: outcomes for infants and children. Sydney, Australia: Australian Government. 2010, available at

http://www.familytransitions.com.au/Family_Transitions/Family_Transitions_files/Post\%20Separation\%20 parenting\%20arrangements\%20and\%20developmental\%20outcomes $\% 20$ for $\% 20$ children $\% 20 \% 26 \% 20$ infa nts\%202010.pdf; R. EMERY, supra note 90, at 118-19 (2010); Tornello et al., supra note 38 For a balanced discussion of both attachment and balanced parenting perspectives, See Marsha Kline Pruett, Jennifer E. McIntosh and Joan B. Kelly, Parental Separation and Overnight Care of Young Children, Part I: Consensus Through Theoretical and Empirical Integration, 52 FAM. CT. REV. 240, 242-47 (2014).

105 For a judicial perspective, see Gerald R. Hardcastle, Joint Custody: A Family Court Judge's Perspective, 32 FAM. L.Q. 201, 212-13 (1998):

Further, joint custody is a more expensive proposition than sole custody. Joint custodians are each required to maintain suitable housing for children, with extra clothing and toys. It has been estimated that these expenditures constitute from one-fourth to one-third of the total child-related expenditures. Initially, there is the question of whether the costs associated with joint custody make such arrangements feasible for low-income families. One study noted that joint custody is not spreading very quickly to lower socio-economic populations. Reviewing the literature, one is left with the feeling that joint custody is an upper-middle class phenomenon.

Such considerations are relevant to young adults whose parents separated. Nuffield Report, supra note 27, at xviii.

106 See, e.g., Ira Lupu. The Separation of Powers and the Protection of Children, 61 U. CHI. L. REV. 1117 (1994). This is not the same as the contention made by some in the same-sex marriage movement 
stability of whatever arrangement is reached. Some research from Australia shows advantage from the child's being considered - being heard - even though other considerations make up the final decision. ${ }^{107}$

The fit parents primarily (assuming Parham is correct) seek to maximize the benefits and long-term happiness of the child. They may also seek some sort of just compensation for their past sacrifices or recognition for the roles they have played, in sociological terms, as father or mother. They may very much value the societal trust given to their parenting, particularly at a time when their trust in their own spouse or partner is at low ebb. ${ }^{108}$ To a lesser extent, they may consider the feelings of the other parent, either in terms of revenge or possibly beneficence. Note again that they are unable to use damages (property compensation) to offset losses of parenting, either because they are constrained by statutes, have little property, or because compensation won't suffice.

Society's interests at separation are to discover and further the "best interests" of the particular child while minimizing strategic behavior by parents, as well as the various kinds of costs noted already. Of course there are difference between looking case-bycase ("ex post"), when we are more interested in the first societal interest and long term ("ex ante"), when we are more interested in the set of costs. This long-term role is the typical role for policy makers and academics and may be one reason we have focused on the bargaining, rather than the litigating, share of disputes.

In sum, at the present time, courts, legislatures, family lawyers, therapists, and interest groups are all focused on changing or maintaining the standards used to determine how to devise the best rules for children whose parents no longer live together. ${ }^{109}$ The pressure of the arguments has increased to the point where in January of 2013 the Association of Family and Conciliation Courts called a meeting (complete with a facilitator to handle disputes) to see whether any rapprochement between the various players (including some from Canada and Australia) could be made using the available scientific evidence. ${ }^{110}$ Although the divorce rate in the United States has continued to fall

debate that men and women are complementary in marriage. See, e.g., Ryan T. Anderson, Marriage: What it Is, Why it Matters, and the Consequences of Redefining It, Heritage Foundation, available at http://www.heritage.org/research/reports/2013/03/marriage-what-it-is-why-it-matters-and-theconsequences-of-redefining-it.

$107 \quad$ McIntosh et al., supra note 104.

$108 \quad$ Brinig and Nock, supra note 89.

109 There is virtual consensus, both among academics and legislatures, that joint decision-making (or "joint legal custody") tends to produce preferable results for fit parents in most situations. All U.S. statutes now allow it, and many have strong presumptions that it is appropriate. For a chart listing these, Elrod \& Spector, supra note 81, at 758 \& Chart 2 (2009). This piece, however, considers shared parenting time, or joint physical custody. The facilitator was Bernard Mayer of Notre Dame's KROC Institute for International Peace Studies.

110 Association of Family and Conciliation Courts, Shared Parenting Think Tank, Closing the Gap: Research, Practice, Policy and Shared Parenting, Chicago, IL, Jan. 24-26, 2013. A final report was published in the April, 2014 issue of Family Court Review, as Pruett \& DiFonzo, supra note 11, and the special issue also includes various subgroup reports. 
since its peak in 1981, so that it is just about what it was in $1970,{ }^{111}$ family dissolution disputes involving children continue to increase. That is so because the unwed birth rate has risen dramatically since 1960, so that in 2010 it was about $41 \%,{ }^{112}$ and unmarried couples, who do not of course divorce, are not as stable as their married counterparts. ${ }^{113}$

Presumptions in some ways seem the ideal way of moving from the over-flexible best interests standard to a situation facilitating bargaining without straitjacketing courts. They would seem to maximize the possibility that all the goals of the custody proceeding can be met. However, custody presumptions, like absolute rules, require that most separating families be fundamentally alike, since, like rules, they act to "pool" parenting situations. However, families with children differ along many important dimensions even when parents are "fit," meaning that their abilities to parent will not typically be questioned or interfered with by the state. ${ }^{114}$

\section{How parents are not alike}

Parents are not alike, though literature says all happy families may be. ${ }^{115}$ They differ in easily observable and measurable ways as well as more subtle, psychological ones. The very differences between parents in intact families may aid children, ${ }^{116}$ though these same differences may make growing up more challenging for children whose parents no longer live together. ${ }^{117}$

The academic literature has discussed some of these differences, and how they may make the typical "one size fits all," or in Ayres/Mitts terminology, "pooling" approach of legal regulation difficult at best, counterproductive at worst. ${ }^{118}$ The data we have obtained from Arizona court records allows us to trace the influence of some, but not all, of these differences.

In work using the National Longitudinal Survey of Adolescent Health, Brinig and Nock noted racial differences in the impact of legal status (their parents' marriage or

111 See, e.g., Dana Rotz, Why Have Divorce Rates Fallen? The Role of Women's Age at Marriage, 2012 (under review); Betsey Stevenson \& Justin Wolfers, Marriage and Divorce: Changes and Their Driving Forces, 21 J. ECON. PERSP. 27 (2007).

112 National Vital Statistics Report 61(1) (Aug. 12,,2012), Births: Final Data for 2010, Table C, available at http://www.cdc.gov/nchs/data/nvsr61/nvsr61_01.pdf (40.8\%)

113 M.D. Bramlett \& W.D. Mosher, Cohabitation, Marriage, Divorce and Remarriage in the United States. National Center for Health Statistics, Vital Health. Stat. 23(33)(2002), available from hppt://www.cdc.gov/nchs/data/series/sr_23/sr23_022.pdf. (The probability of a cohabiting relationship lasting even five years is $51 \%$, compared to $80 \%$ for marriage.)

$114 \quad$ Elizabeth S. Scott \& Robert E. Scott, Parents as Fiduciaries, 81 VA. L. ReV 2401 (1995).

115 LEO TOLSTOY, ANNA KARENINA 1 (1878) (““'All happy families are alike; each unhappy family is unhappy in its own way.")

116 Lupu, supra note 106.

117 ElIZABETH MARQUARDT, BETwEEN Two WorLDS: THE INNER LIVES OF CHILDREN OF DIVORCE (New York: Crown Pubs. 2005)

118 See, e.g., Bartlett,supra note 78, at 468 (1999)(one-size-fits-all produces lousy results for some individual children). 
formal adoption) on various groups of children. The bottom line was that for some U.S. children, marriage (rather than staying together) affects wellbeing in numerous ways. For others, if their parents live together it does not seem to matter whether they are married or not. ${ }^{119}$ Similarly, for most children, living in a birth or adoptive family is far preferable to living in an informal family with kin. For African-American children, living with kin is virtually indistinguishable from adoption or living with biological parents. ${ }^{120}$ (For all children, living with foster parents is the least preferable situation, ${ }^{121}$ though whether it is the foster families or the events leading to placement that is problematic is not revealed by the data.)

Using the National Longitudinal Survey of Youth (1979), Brinig documented differences in responses to varying parenting styles following the patterns of Baumrind ${ }^{122}$ and Maccoby and Martin, ${ }^{123}$ finding, consistent with other literature ${ }^{124}$ that AfricanAmerican children responded more favorably to authoritarian parenting than did majority children, who had better results with either authoritative or permissive parenting styles. In Israel, Dwairy and Dor ${ }^{125}$ have noted that different immigrant groups to Israel seem to do better under different parenting styles, while Mayseless and coauthors ${ }^{126}$ have found best adaptation to the Israeli military following authoritative parenting. All these studies can be taken to caution lawmakers from assuming that policies directed at families will always have the same results, even when implemented in good faith. While we cannot directly measure parenting style given our data here, we can detect any differences Hispanic culture makes, because a number of the separating parents in the Arizona sample who are self-or other identified as Hispanic. ${ }^{127}$

Other observable characteristics that might make differences include income, whether the parents had ever married, whether either parent displayed signs of alcohol or

\footnotetext{
119 The One-Size Fits All Family, 49 SANTA Clara L. REV. 1371 (2009)

120 Margaret F. Brinig and Steven L. Nock, How Much Does Legal Status Matter? Adoption by Kin Caregivers, 36 Fam. L.Q. 449, 463 (2002).

121 Id. at 462-63.

122 Diana Baumrind, The Influence of Parenting Style on Adolescent Competence and Substance Use, 11 J. Adolescence 56 (1991)

123 Eleanor Maccoby \& Martin, Sociology in the Context of the Family: Parent-Child Interaction, In P.H. Mussen (Series Ed.) \& E.M. Hetherington (Vol. Ed.), Handbook of Child Psychology (vol. 4): Socialization, Personality, and Social Development (pp. 1-101). New York: Wiley.

$124 \quad$ Beau Abar, Keith L. Carter \& Adam Winsler, The Effects of Maternal Parenting Style and Religious Commitment on Self-Regulation and Achievement and Risk Behavior Among African-American Parochial College Students, 32 J Adolescence 759 (2009)

$125 \quad$ Marwen Dwairy \& Asnat Dor, Parenting and Psychological Adjustment of Adolescent Immigrants in Israel, 23 J. Fam. Psych. 416 (2009).

126 Ofra Mayseless, Miri Scharf, \& Michel Sholt, (2003). From authoritative parenting practices to an authoritarian context: Exploring the person-environment fit. Journal of Research on Adolescence, 13(4), 427-456

127 In some cases, one or the other of the parents still had homes in Mexico, was currently living there, or had married there. In others, the divorce records had forms answered in Spanish, or featured hearings requiring an interpreter. In some of those with protective orders or bench warrants, the assailant or victim was identified as Hispanic in police reports. Finally, in some we followed Census methods, using the probabilities from the list of most common Hispanic surnames weighted by the Hispanic percentage population in the census tract.
} 
drug abuse or mental illness, whether the relationship was characterized by domestic violence, and whether the child was an infant at the time of separation. Indications that courts were dealing with the less favorable of these types of families might indicate that absent agreement, a court should not award equal or even substantially shared parenting. ${ }^{128}$ A number of prior studies, most notably the recent one done by Melli and coauthor in Wisconsin, ${ }^{129}$ indicate that equal or substantially shared parenting is most common in wealthy couples. ${ }^{130}$ On the contrary, many jurisdictions disallow substantial custody to be awarded the perpetrator of domestic violence, ${ }^{131}$ while most place substantial restrictions or supervision requirements on parents who abuse substances or whose mental illness may endanger themselves or the child. ${ }^{132}$ Even many advocates of shared parenting in general hesitate to endorse it when children are infants. ${ }^{133}$

Other possible differences that can be measured in the Arizona data include the way the parenting plan was reached, whether by default, consent, or after contested court hearing. ${ }^{134}$ Most of the early studies of joint custody success involve parents who opted into shared parenting either before separation or fairly early in the divorce process. ${ }^{135}$ One might expect these couples to be more successful as co-parents than those parents who each initially favored sole custody awards to themselves or who are otherwise unable to settle the incidents of divorce. ${ }^{136}$ Most of the statutes listing factors for when

\footnotetext{
128 See, e.g., Peter Jaffe, A Presumption Against Shared Parenting for Family Court Litigants, 52 FAM. CT. REV. 187, 188, 191 (2014).

129 Melli \& Brown, supra note 49; Judi Bartfeld, Shared Placement: An Overview of Prevalence, Trends, Economic Implications, and Impacts on Child Well-Being, University of Wisconsin Institute on Poverty, 2011. See also Suzanne Reynolds, Ralph Peoples \& Catherine Harris, Back to the Future: An Empirical Study of Child Custody Outcomes, 85 N.C. L. REV. 1629 (2007).

130 There is also evidence that parents with substantial higher education may favor equal or joint parenting, though this characteristic is highly correlated with income.

$131 \quad$ See, e.g., ARK. CODE § 9-13-101@(2); Idaho Code § 320717B(5); Minn. Stat. § 518.17 subd. 2.

$132 \quad$ See, e.g., WIS. STAT 767.41 (5)(am) (14); ALI PRINCIPLES, supra note 9, § 2.13.

133 See Pruett \& DiFonzio, supra note 9, at 162:

Embedded within the shared parenting research is a hotbed of controversy on the question of overnights for fathers with very young children who do not primarily reside with them. As indicated, early paternal involvement serves as a protective factor for later father-child relationships. Yet the primacy of attachment research paradigms for mapping the pathway to healthy development has led to dyadic considerations of security and stability that have, until very recently, excluded the father or other caregiver. The emphasis on assisting parents through a conflict-laden transition, while their children's brains and minds are developing rapidly and in need of consistent nurturance and support in order to develop physiological and biological regulation and trust in the world around them, can pit the uncoupling family's dynamics in direct opposition to the child's capacities and needs.
}

See also Marsha Kline Pruett, Jennifer E. McIntosh \& Joan B. Kelly, Parental Separation and Overnight Care of Young Children, Part I: Consensus Through Theoretical and Empirical Integration, 52 FAM. CT. REV. 240 (2014) (suggesting that for young children the decision needs to be individualized); Indiana Parenting Time Guidelines, supra note 69; also Tornello et al., supra note 38 Some of the debate among researchers seems to emanate from differences in their belief in attachment theory.

134 A final variation, inconsistently titled by the two observed courts, is that the arrangement was negotiated by attorneys and confirmed in the final court hearing.

135 An exception is Robert E. Emery, Sheila G. Matthews and Katherine M. Kitzman, Child Custody Mediation and Litigation: Parents' Satisfaction and Functioning One Year After Settlement, 62 J. CONSUlt. \& CLINICAL PSYCH. 124 (1994).

136 See also Pruett \& DiFonzo, supra note 9, at 154. 
joint physical custody is appropriate mention distance. ${ }^{137}$ While children may be able to flourish moving between two households in the same neighborhood and school district, keeping their friends and classrooms constant, equal parenting becomes increasingly difficult as parents are located at greater distances. Frequent contact with both parents, one of the goals of many of the statutes, ${ }^{138}$ is impossible once travel takes more than a couple of hours.

\section{Herding and Separating Models in the Context of Child Custody.}

This article began with the observation that law professor Ian Ayres and attorney Joshua Mitts write that traditional regulatory schemes, imposing across-the-board mandates to regulate externalities, move behavior from many simply mimicking others to a new, mandated pool. They argue that this can be less useful for society than a system where regulation induces separating behaviors, since pooling suppresses the production of information and may exacerbate systemic risk. The information-production function suppressed by pooling can otherwise steer both private and public actors toward better evidence-based outcomes. ${ }^{139}$

The Arizona law in place at the beginning of my study was typical of the rules in many states "friendly" to joint parenting, allowing mimicking rather than more strongly channeling shared parenting. ${ }^{140}$ The state moved in $2010^{141}$ and again in $2012^{142}$

137 For some examples, see WASH. REV. CODE $§ 26.09187(3)(\mathrm{b})$; ALA. CODE $§ 30-3-$

152(a)(5)(geographic proximity of parents to each other as this relates to the practical considerations of joint physical custody); N.MEX. STAT. § 40-4-91B(7)(“geographic distance between the parties' residences"); WIS. STAT. § 767.41(4)(a)(2).

138 See, e.g., TEX. CODE ANN §153.0001( a)(1)(“frequent and continuing”); VA. CODE § 20-

124.2(B)("frequent and continuing"), Wis. Stat. \$767.41 (regularly occurring and meaningful periods of physical placement to provide predictability and stability")

$139 \quad$ Ayres and Mitts, supra note 1, at 3.

140 ARIZ. REV. STAT. § 25-403.01. Sole and joint custody

A. In awarding child custody, the court may order sole custody or joint custody. This section does not create a presumption in favor of one custody arrangement over another. The court in determining custody shall not prefer a parent as custodian because of that parent's sex.

B. The court may issue an order for joint custody over the objection of one of the parents if the court makes specific written findings of why the order is in the child's best interests. In determining whether joint custody is in the child's best interests, the court shall consider the factors prescribed in section 25-403, subsection A and all of the following:

1. The agreement or lack of an agreement by the parents regarding joint custody.

2. Whether a parent's lack of agreement is unreasonable or is influenced by an issue not related to the best interests of the child.

3. The past, present and future abilities of the parents to cooperate in decision-making about the child to the extent required by the order of joint custody.

4. Whether the joint custody arrangement is logistically possible.

C. The court may issue an order for joint custody of a child if both parents agree and submit a written parenting plan and the court finds such an order is in the best interests of the child. The court may order joint legal custody without ordering joint physical custody.

Child Custody, 2005 Ariz. Legis. Serv. Ch. 45 (S.B. 1045) (West).

$141 \quad$ Laws 2010, Ch. 186, $\$ 2$.

142 Laws 2012, Ch. 309, § 8, eff. Jan. 1, 2013 
progressively toward mandating equal parenting for all separating couples. ${ }^{143}$ Arizona as a whole even in 2007 had more equal parenting than most other jurisdictions, ${ }^{144}$ and Maricopa County, the most populous in the state, led the way and drives the state-level results. ${ }^{145}$ In other words, by imitating others, the majority of couples not having trialdetermined custody outcomes, chose some degree of joint parenting, and the most frequently occurring single outcome was equal or nearly equal parenting. ${ }^{146}$ The figure also shows peaks or concentrations at various other points, though these may be due to incentives driven by the shared custody deductions of the child support system.

143 ARIZ. REV. STAT. $\$ 25-403.02$ now includes in part:

B. Consistent with the child's best interests in $\S 25-403$ and $\S \S 25-403.03,25-403.04$ and 25-403.05, the court shall adopt a parenting plan that provides for both parents to share legal decision-making regarding their child and that maximizes their respective parenting time. The court shall not prefer a parent's proposed plan because of the parent's or child's gender.

144 SEE PATRICK PARKInson, THE PAYOFFs AND PITFAlls OF LAWS THAT ENCOURAGE SHARED PARENTING: LESSONS FROM THE AUSTRALIAN EXPERIENCE, 13 (2014). North Carolina in 2006 had $15.3 \%$ of cases with at least 123 days of parenting time (33\%), Reynolds et al., supra note 29, at 1667 (2006-07); Oregon, in 2002, had $32 \%$ of joint custody according to MARGARET F. BRINIG, LAW, FAMILY AND COMMunity: SupPorting THE COVEnANt 89 \& Fig. 2.1 (2010); Wisconsin had 43.8\% with at least 30\% parenting time in 2007, according to Bartfeld, supra note 129 (2011); Washington in 2007 had 16\% equal and another $18 \%$ over $35 \%$ according to Thomas George, Residential Time Summary Reports Filed in Washington July 2007-March 2008, Olympia: Washington State Center for Court Research, available at www.courts.wa.gov/wsccv/docs/ResidentialTimeSummaryReport.pdf; Arizona in 2007 had 15\% equal custody, and another 19\% with at least 116 days, according to Venohr \& Kaunelis, Arizona Child Support Guideline Review: Analysis of Case File Data. Denver: Center for Policy Research, available at www.azcourts.gov/Portals/74/CSGRC/repository/2009-CaseFileRev.pdf.

145 Because Maricopa's population is so much larger than any other county in the state, its custody numbers drive the state averages. Pima's (and presumably other counties') are skewed to the left, the lower amounts. Pima's totals were slightly different (added up to only 91\%) because of a large number of cases in which no parenting time reduction was ordered. These do not show up on the figure (which begins at 420 days).

146 The various spikes in the figure correspond, by definition, to frequently occurring parenting patterns. While the 182 day pattern is obvious (though it may be through alternating weeks or seasons, or 2-2-5-5 day patterns), the spike around 60 days accounts for traditional custody arrangements (every other weekend (52 days) plus one week during the summer (4.75 additional days). The 104 day pattern is for one parent to have the children during the school week with the other living with them on weekends (or, in long distance situations, one having most of summer vacation plus the longer breaks during the school year). 


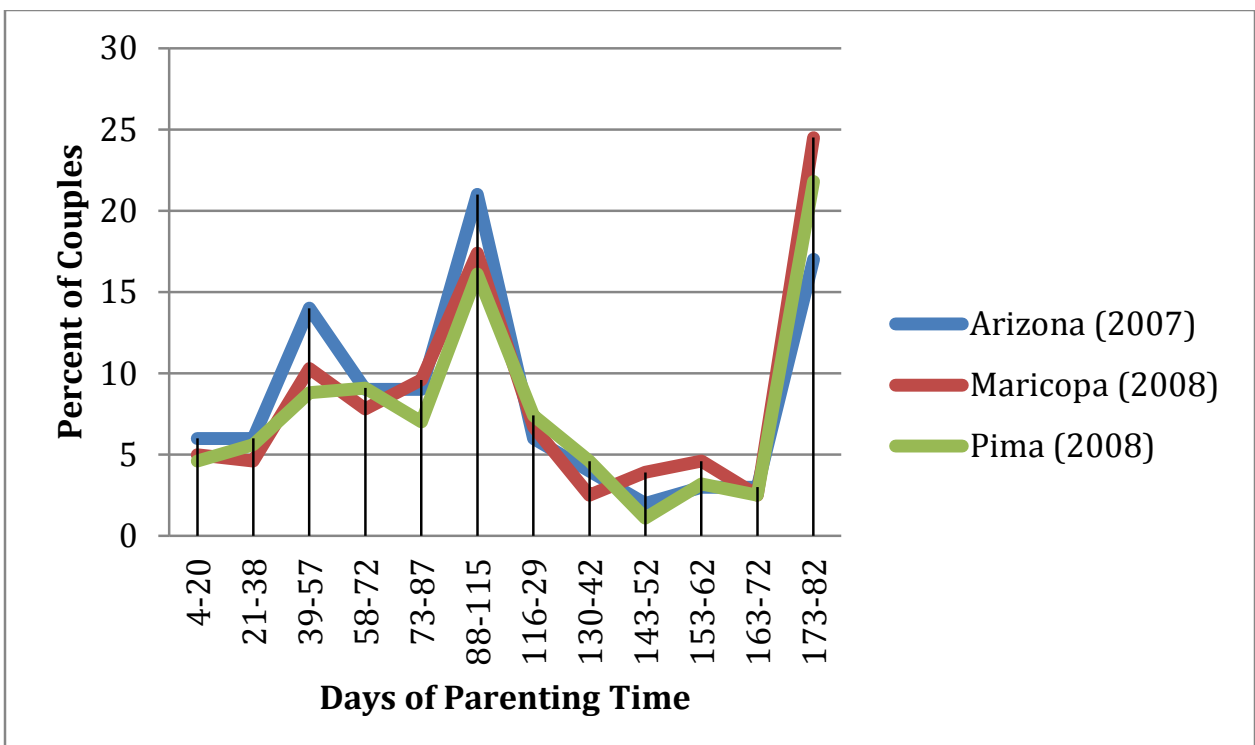

Sometimes, as Ayres and Mitts point out, moving from mandatory (such as the rule all mothers got custody under a tender years presumption) to a default (joint parenting) will induce more separation, that is, a smoother distribution across all the points. The authors' illustration is that with home schooling as an exception from compulsory public or private education, there will be more experimentation. ${ }^{147}$ Ayres and Mitts suggest that such defaults may induce separation when there is no regulatory transparency. This would be true in the custody situation only if all decisions were kept confidential. Clearly each judge knows his or her past decisions (and almost certainly is attempting to apply the law in a consistent way). ${ }^{148}$ But every attorney also knows what has happened with clients, and attorney CLE courses and other meetings facilitate the spread of general custody patterns as well as what worked in a particular kind of case. ${ }^{149}$ The talk spread in

147 Private schooling was constitutionally permitted as an option in Pierce v. Society of Sisters. Homeschooling became increasingly popular following Wisconsin v. Yoder, 406 U.S. 205 (1972) (allowingAmish parents to be exempt from compulsory education through age 16 in order to pursue the home-based vocational education commensurate with their religious tradition).

148 This prior tendency/self-knowledge would be evidenced in written opinions, but these are highly unlikely in family law matters precisely because of the discretion accorded to trial court judges. The class of cases in which the judge's tendency to "clump" might occur is those decided by the court, in Maricopa known as DDI, or decree of dissolution after trial. The judges, of course, might be influenced by many things, including, according to a recent study (that only observed the tendency in women's rights cases) whether they have daughters. Glynn, Adam, and Maya Sen. 2014. Identifying Judicial Empathy: Does Having Daughters Cause Judges to Rule for Women's Issues?. American Journal of Political Science. Copy at http://j.mp/NzXAEG.

149 This herding effect would be most pronounced in those cases decided by consent, termed by Maricopa Consent Decrees of Dissolution. In Mnookin \& Kornhauser, supra note 12, terminology, these would be bargains reached "in the shadow of the law." In an online survey taken in May, 2014, of members of the family law section of the state bar in Maricopa, with 57 responses, the changes made to the law in 2013 would primarily affect judges' decisions, not what they advised their clients, and then only make a difference to fathers seeking equal custody. More than half (52.6\%) answered that the change made no or minimal change in the way their clients would reach parenting time decisions. The same survey revealed that two-thirds $(66.7 \%)$ felt that the new law would make at least a moderate difference to judges deciding contested custody cases. The number of fathers who would likely be successful in obtaining equal 
divorced and single parents' support groups or just among casual friends also may induce people to follow trends like shared parenting. ${ }^{150}$ In such cases, where others' practices are known, Ayres and Mitts show how Bayesian decisionmaking will induce pooling, as actors "find it individually more rational to mimic the tried-and-seemingly-true behavior of others rather than to take the road less traveled. ${ }^{151}$

Ayres and Mitts write at greatest length ${ }^{152}$ about the tendency of pooling regulations to increase the chance of systemic risk. ${ }^{153}$ There is no exact analog in the custody world, where individual failures are the legal concern. ${ }^{154}$ However, to the extent that racial and cultural groups, or lower income families, are disadvantaged by particular parenting arrangements, the exacerbation of income inequalities would present a major problem. ${ }^{155}$ This type of systemic risk is what some of the results in Arizona seem to portend. ${ }^{156}$ There is also the possibility, discussed elsewhere ${ }^{157}$ and therefore left to the side here, that the shared custody presumption is internally a bad choice

parenting time $(81.7 \%)$ following the law was much greater than prior to the law $(47.3 \%)$. Survey responses available on request to author.

${ }_{150}$ For one thoughtful discussion of social norms, see Richard C. McAdams, Focal Point Theory of Expressive Law, 79 VA. L. REV. 339 (2000). For the original paper coining the term "norm entrepreneurs," see Cass Sunstein, Social Norms and Social Roles, 96 Colum. L. REV. 903 (1996). Arguably the divorced fathers groups have played major roles in moving norms toward joint parenting.

$151 \quad$ Ayres \& Mitts, supra note 1, at 4.

152 See also Ian Ayres \& Joshua Mitts, Three Proposals for Regulating the Distribution of Home Equity, 31 YALE J. ON REG. - (2014).

153 See their Figure 2 on page 6. Note the similarity with the bunching in Arizona at parenting times of 39-57 days (.05\% subtraction from child support according to Appendix A, 88-115 days (16.1\% subtraction from child support); and 173-82 days (48.6\% subtraction, or 50\% under Schedule B).

154 There has been much concern about a particular kind of systemic risk, that dealing with interracial placement of children, which might adversely affect the racial minority groups themselves. For a consideration of this risk, see Margaret F. Brinig, Book Review, The Child's Best Interests: A Neglected Perspective on Interracial Intimacies, 117 HARVARD LAW REVIEW 2129 (2004).

155 For a discussion of this problem in the context of marriage, see JUNE CARBONE \& NAOMI CAHN, MARRIAGE MARKETS (Oxford University Press, forthcoming 2014).

156 Depending upon the success of shared parenting, there may be a risk from its under-use by less advantaged or cultural minority families. That is, if children of separating parents do much better when their parents share parenting, whole groups of children are at risk. On the other hand, if income inequality between parents presents special problems for equal-parenting separated couples because of faulty assumptions behind the child support guidelines, there could be another unhappy systemic effect that would only be worth the cost if the benefits of coparenting outweighed the documented risks of growing up (at least partially) in poverty. As far as I know, no research has been done on growing up in two households, one of which is far poorer than the other. This result was certainly not the goal of the child support guidelines, and in some jurisdictions (Canada, for example), is expressly what is being avoided by very generous awards to the lower income parent. See Allen \& Brinig, supra note 34, at 146-47(2011).

157 Brinig, Penalty Defaults, supra note 10. 
Figure 2: The Effect of Potential Shocks on Pooling v. Separating Equilibria

Pooling Equilibria

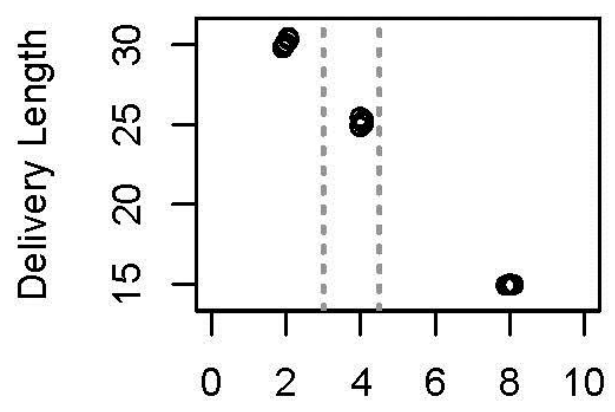

Price
Separating Equilibria

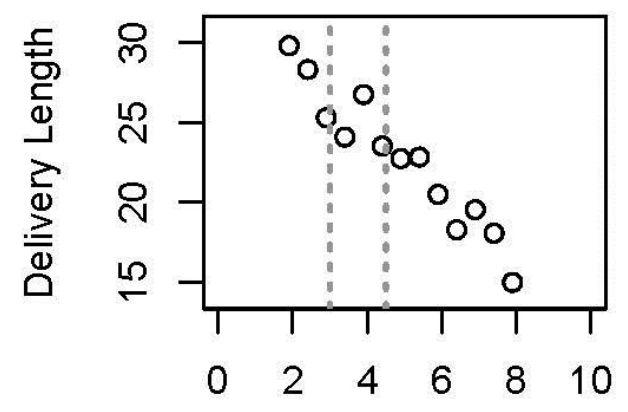

Price

Ayres and Mitts say that pooling may result if "the cost of altering the default is sufficiently high." 158 In the custody context, this may well be the case with the latest version of the statute, which requires the judge to order a parenting plan that maximizes the parenting time for both parents. In order to deviate from the statute, the judge would presumably have to list specific reasons under the other sections (such as domestic violence) that such an order is not appropriate. ${ }^{159}$ While Arizona law restricts joint legal decisionmaking (joint legal custody) in cases of domestic violence, a finding that domestic violence occurred does not necessarily affect the decision that the parties should share parenting time, and a decision affecting parenting time would require a (high cost, in terms of court time, legal fees, missed work and emotional energy) ${ }^{160}$ additional hearing and a finding that substantial parenting time would endanger the child. ${ }^{161}$ Ayres and Mitts repeat the familiar modern portfolio theory, which presupposes that distribution across different investments reduces the chance of correlation among them and thus of failure given market loss. ${ }^{162}$ However Ayres and Mitts extend the theory in successive sections to biodiversity and ecosystem stability, ${ }^{163}$ genetic variation and population survival, ${ }^{164}$ and even types of political regimes (democratic and dictatorial types were

$158 \quad$ Ayres and Mitts, supra note 1 , at 8 \& fn. 14.

159 ARIZ. REV. STAT. § 25-403(B) provides:

B. In a contested legal decision-making or parenting time case, the court shall make specific findings on the record about all relevant factors and the reasons for which the decision is in the best interests of the child.

160 See Mnookin \& Kornhauser, supra note 12 at 971-72.

161 ARIZ. REV. STAT. $§ 25-403.01$ provides:

D. A parent who is not granted sole or joint legal decision-making is entitled to reasonable parenting time to ensure that the minor child has substantial, frequent, meaningful and continuing contact with the parent unless the court finds, after a hearing, that parenting time would endanger

162 the child's physical, mental, moral or emotional health.

$163 \quad$ Id. at $11-13$.

$164 I d$. at 13-15 (where variation in the variation, or kurtosis, is essential to systemic stability given unexpected shocks to the system). 
both needed to repel Hitler's Nazi invasion). ${ }^{165}$ In modern pluralistic families, a variety of parenting arrangements accommodate parents who live and work in a variety of settings. ${ }^{166}$

Much of the rest of Ayres and Mitts' paper is devoted to consideration of the benefits of separating equilibria for generating information and for experimentation, and this application of their theory seems to apply most closely to shared custody presumptions. They maintain that "diversity permits learning of better outcomes in alternative states of the world." 167 One of the historic problems with sweeping legal rules in the family area is that their effects often are not measured, ${ }^{168}$ or are not measured in scientifically valid ways before they are copied. ${ }^{169}$ In particular, in many of the papers supporting joint parenting, families opted into the arrangement, or the groups studied were very small or in particular geographic areas. Much less research supports the success of laws defaulting to substantial or equal co-parenting among divorcing families ${ }^{170}$ (let alone families who never married and may never have lived together). ${ }^{171}$

$165 \quad I d$. at $25-16$.

166 Thus Maria Cancian et al., Who Gets Custody. Now? Dramatic Changes in Children's Living Arrangements After Divorce, DEMOGRAPHY (forthcoming 2014) note that shared parenting is much more likely to be chosen (by parties or judges) in Wisconsin counties other than the most urban, Milwaukee, which also boasts the greatest minority populations.

$167 \quad$ Ayres \& Mitts, supra note 1, at 16.

168 As Pruett \& DiFonzo, supra note 11, at 161:

For example, areas of research with strong supporting bodies elucidate both the harm to children due to continued exposure to parental conflict, and the important protective factor of positive quality parenting by both parents. In contrast, under what conditions and how best parents in moderate conflict can continue to share decision making and parenting time exemplifies an area about which we do not have a sufficient body of knowledge to recommend policy. Similar concerns underlie the question of when having children alternate between two homes on a regular basis becomes more anxiety producing than beneficial.

169 The classic example here is the famous study on mandatory arrest following a police call for domestic violence. When the Minneapolis findings (carefully made through randomized trials) suggesting that mandatory arrest would reduce recidivism by aggressors were replicated in other cities, a number showed precisely the opposite result. Nonetheless, mandatory arrest remains the solution of choice. See Lawrence Sherman et al., Crime, Punishment and Stake in Conformity: Legal and Informal Control of Domestic Violence, 57 AM. Soc. REV. 680 (1992); and Lawrence W. Sherman et al., The Effects of Arrest on Criminal Careers: The Milwaukee Domestic Violence Experiment, 83 J. CRIM. L. \& CRIM. 137 (1992).

The recent legislative success of proponents of more equal co-parenting may be thought of as just such a "informational cascade," (Ayres and Mitts, supra note 1, cite to Sushil Bikhchandani, David Hirshleifer \& Ivo Welch, A Theory of Fads, Fashion, Custom, and Cultural Change as Informational Cascades, 100 J. POL. ECON. 993 (1992); and Sushil Bikhchandani, David Hirshleifer \& Ivo Welch, Learning from the Behavior of Others: Conformity Fads, and Informational Cascades, 12 J ECON. PERSPECTIVES 151 (1998). enhanced of late by blogs, websites and the intense lobbying efforts of men's groups. Such groups will eventually propagate ideas about the availability of equal parenting through the separating parenting world as well. In Arizona, the custody law reforms of 2012 were preceded by an intensive media campaign.

170 See, e.g., Pruett \& DiFonzo, supra note 11, at 162: (“As a result, participants at the think tank cautioned that the nuances apparent in the current literature on parenting time call for parental agreement or individualized judicial assessments rather than decisions premised on legal presumptions..”)

171 See, e.g., Pruett \& DiFonzio, supra note 11, at 168:

It is inappropriate to have a presumption that covers all situations when not enough is known to verify that the presumption will benefit almost all children and families. Presumptions appear in the law as a blunt instrument, yet we know very little empirically about how a presumption would 
Research has shown that re-partnering (through a second marriage or otherwise) does affect child wellbeing. Again, there is no systematic look on how well it works, from the child's perspective, in cases of shared parenting. ${ }^{172}$ Most separating couples will repartner, though the new union is less likely to be remarriage for minorities. ${ }^{173}$

Following Ayres and Mitts' explanation, once some number of parents have voiced favorable opinions of joint parenting, others, in the face of uncertainty about it or even prior mild opposition, will opt in, ${ }^{174}$ causing a series of pooling equilibria. These, in turn, prevent discovery not only of which terms (here, parenting arrangements) are more effective on average, but also "whether some are more effective under different conditions such as locations and even time," precisely the problem with default custody rules. ${ }^{175}$ The authors suggest menu approaches, which may induce separating equilibria whenever the cost of individualized negotiations for an alternative set of terms exceeds the cost of contracting under the menu. ${ }^{176}$ After a discussion of applications to the recent financial crisis, the authors conclude with "The Parable of the Bridges," 177 explaining how in 1850, the Angers Bridge collapsed when a battalion of French soldiers marched across it, spontaneously falling into step with the bridge's vibrations, inadvertently amplifying them. This, too, is a kind of pooling that may amplify systemic risk, and a laissez-faire approach will not always work, according to Ayres and Mitts, who suggest mandating or actively encouraging non-uniformity. ${ }^{178}$ Legislation that encourages the formulation of individualized parenting plans without a single default custody pattern like Arizona's equal parenting default would maximize non-uniformity, better serving both individual children and a future society in which more and more separating couples will be unmarried. ${ }^{179}$

\footnotetext{
apply to same-sex couples, nonbiological parents, never-married partners who had no significant partnership before having a child together, and so on.

172 Ayres \& Mitts, supra note 1, suggest explicit randomized testing of law and regulation. Id. at 17, suggesting that "separating equilibria complement randomization: the latter facilitates causal inference while the former expands society's knowledge regarding the covariance of potential outcomes with varying type of contractual equilibria." Id. at 24. While divorcing parents in Arizona are not presented with menus, the forms many use for divorce, custody and support do present a menu look: do you want sole custody (with or without supervision?) or joint custody (with or without a primary custodian), and, for parenting plans, what do you want to do during the school year? The summer? For extended holidays? For nonweekend holidays?

173 Bramlett \& Mosher, supra note 113. Pruett and DiFonzo express some concern about shared parenting with this group. Pruett \& DiFonzo, supra note 11, at 166.

$174 \quad$ Ayres \& Mitts, supra note 1, at 18.

$175 \quad$ Ayres \& Mills supra note 1, at 20.

176 Ayres \& Mitts, supra note 1, at 24. They use haggling over new car prices as an example of a task that might be more happily accomplished through a limited menu of prices and financing terms. A menu approach to be used by mediators is suggested in R. Emery, supra note 90, at 186, based upon the age of the child and the amount of conflict in the parents' relationship.

$177 \quad$ Ayres \& Mitts, supra note 1, at 40.

$178 \quad$ Ayres \& Mitts, supra note 1, at 41.

179 This brings us back to the summary of the Think Tank meeting on shared parenting complied by Pruett and DiFonzo, supra note 11, who wrote (1) The most effective decisionmaking about parenting time is inescapably case-specific, and (2) statutory presumptions prescribing specific allocations of shared parenting time are unsupportable because no prescription will fit all, or even the majority of families' particular circumstances. Id. at 153-54.
} 


\section{An Empirical Test of Pooling Models: Randomized Cases from Maricopa}

When I set about looking for particular jurisdictions in which to study the effect of preferences for shared parenting and child support laws, I had several criteria: first, a "modern" statute, that is, one that talked in terms not of custody and visitation but in terms of parenting time. Second and relatedly, I wanted a state that for some time had parenting guidelines propounded by the judiciary to give additional guidance to judges making parenting time decisions. Third, I preferred to analyze states that had comparable child support guidelines, especially in the way they treated substantially shared parenting. Fourth, given the first criteria, I looked for states with substantial experience with shared parenting: that is, states likely to be above average in shared parenting awards. And last, I needed states that would allow me remote access to electronic records. This required that the counties involved at least keep electronic records of not only judicial activity (or minute entries), but also scanned documents such as pleadings, reports of various kinds, motions, and decisions and orders of judges, mediators, and so forth. The two states I ultimately chose were Arizona and Indiana. At the time of this writing, I have just received permission to access the Indiana files, but have received and closely studied records from the two most populous counties in Arizona, Maricopa (which includes Phoenix ${ }^{180}$ and Pima (which includes Tucson), ${ }^{181}$ which together include $81.6 \%$ of the state's residents. ${ }^{182}$

Melanie Fay, who is the Court Administrator in Maricopa County, selected a sample of intake files from eight weeks scattered throughout 2008. These identified not only file names and the type of action involved, but also the names of parties, their addresses (where available), their counsel (or whether, as most couples were, they were self-representing, or "pro per" as it is called there), and very often their dates of birth. From these I randomly selected files representing specific types of actions, ${ }^{183}$ with the following results:

\begin{tabular}{|c|c|c|c|c|}
\hline & Frequency & Percent & $\begin{array}{c}\text { Valid } \\
\text { Percent }\end{array}$ & $\begin{array}{c}\text { Cumulative } \\
\text { Percent }\end{array}$ \\
\hline 601 Dissolution with Children & 363 & 58.5 & 58.5 & 58.5 \\
\hline 602 Dissolution without Children & 51 & 8.2 & 8.2 & 66.8 \\
\hline 621 Legal Separation & 7 & 1.1 & 1.1 & 67.9 \\
\hline
\end{tabular}

180 The 2013 population estimate according to the Census Department is 4009412.

181 The 2013 population is estimate is 996554.

182 The 2013 population estimate is $6,626,624$

183 Please note that while I selected files randomly, I did not attempt to match the actual proportion of files in the sample. Thus while my contrasts within and between groups does not present statistical issues, I am sure that it is not representative of all the cases involving children decided in Maricopa, for instance. The sample underrepresented the population of divorces with children among this group (62.6\% compared with $73 \%$ in the intake weeks represented), slightly underrepresented the unmarried custody cases $(7.37 \%$ compared to $9.7 \%$ in the intake weeks represented) and substantially overrepresented the establishment of support group ( $27.7 \%$ compared to $17 \%$ in the weeks intake represented). 


\begin{tabular}{|l|r|r|r|r|}
\hline 624 Custody & 43 & 6.9 & 6.9 & 74.8 \\
625 Protective Order & 1 & .2 & .2 & 75.0 \\
628 Support & 155 & 25.0 & 25.0 & 100.0 \\
Total & 620 & 100.0 & 100.0 & \\
\hline
\end{tabular}

Many of the legal separations eventually were changed by one of the spouses to a final dissolution. The one protective order case was not analyzed further, though there were protective orders that were part of each of the other types of cases. ${ }^{184}$

There are two kinds of court data involved in the study. The first is publicly available online, ${ }^{185}$ and is simply a listing of transactions with the clerk's office dealing with the file. The most important for analysis purposes is a second grouping within the publically available file, a listing of the (minute) time scheduled with the decisionmaker.

The second kind of data was obtained after receiving institutional review board approval and with assurances that individual records would be kept confidential. It was the actual documents, such as pleadings and other motions, letters, reports, orders, and so forth, involved with each file selected above. These documents contain a host of information. Some are routine or appear in every case involving children. Such documents include affidavits of service of process, orders to complete parenting time education classes (and certifications when they were attended), motions and orders dealing with continuances of various trial dates. Some were quite routine but did not appear in every case, including motions and orders for return of evidence, cash receipts, calculations of arrearages by the department of economic security (since the final numbers would be found elsewhere), and orders of publication when respondents could not be located. The information I coded came from complaints and answers (or motions and responses), reports by child coordinators or of drug testing, completed parental worksheets for child support, parenting plans (joint or sole), and final dissolution orders (or orders dealing with motions or protective orders). The complaint typically included names and birth dates of parents and children, if any, the date of marriage (if the parties were married), addresses, occupations of the parents, what property was owned by the couple and how the petitioner wanted it split, what parenting time was asked for, and whether spousal support or child support was sought. It also indicated which party was bringing the action (father or (at least nominally, in the case of Title IVD support) mother) and whether or not there had been or currently was domestic violence. The answer corroborated or sometimes corrected the details found in the complaint, asking for the same or different things. The child support worksheets at the time of the dissolution or other order identified which parent was the primary custodial parent, what each parent's monthly income was, whether or not either was responsible for additional or

184 Some of these cases were dismissed at various points, and for various reasons. A number (17) couples reconciled and voluntarily dismissed the actions. A perhaps overlapping group of 28 had their cases dismissed by the court for failure to prosecute them. A third group of 16 involved absent parents or children and therefore a lack of jurisdiction to decide custody and/or support issues.

$185 \quad$ Maricopa's are found at http://www.superiorcourt.maricopa.gov/docket/FamilyCourtCases/. Pima's are found at http://www.agave.cosc.pima.gov/home.asp?Include=pages/record_search.htm. 
court ordered support for another child, whether the child was over 12 or had extraordinary expenses, who was ordered to pay child support, what the parenting time of the payor parent was (calculated by totaling the number of days or partial days), and whether the amount was adjusted because it exceeded the amount needed for self-support (in 2008, \$775 monthly). Some cases involved temporary motions for support, requests for custody evaluations or mediation, discovery motions (which I usually ignored unless the total number of these was very large), actions involving protective orders and, if requested, the results of protective order hearings, and motions post dissolution (or order) to increase or decrease child support or parenting time or to enforce either. The motions were accompanied by supporting reasons, which were frequently referred to by the court in resolving them. The divorce decrees or parenting orders incorporated any agreements of the parties, which sometimes were attached and sometimes separately filed. These usually included parenting plans and sometimes included property settlement agreements. The stand-alone support orders included reasons for deviating from the amounts calculated on the worksheet (the state child support guideline amounts) and sometimes employer information (which was also sometimes included in a separate document). All of these alleged or found facts were carefully coded. [A sample worksheet, with identifiers removed, from July of 2008 is appended.]

The child support guidelines explicitly defined and still define ${ }^{186}$ how to count days or partial days for parenting time. ${ }^{187}$ Once the total is determined, a table in the guidelines ${ }^{188}$ reveals what percentage of the obligation should be reduced to obtain preliminary child support owed. For example, the traditional, or "basic," parenting plan would be for the child to spend every other weekend plus one evening during the week plus split holidays plus two weeks in the summer with the non-primary parent. While many parents use a calculator (obtainable as a free download) for this, the plan would include 52 (for the weekends) +3 (12 X .25 for weekend evenings) +5 (for holidays) + 12 days (for summer) $=72$ days, or a $10.5 \%$ reduction. A separate table known as Appendix B equates the total support obligation borne (or imputed) to each parent when parenting time is equal. ${ }^{189}$

186 Arizona Child Support Guidelines, Adopted by the Arizona Supreme Court, as Amended By Executive Order 2011-46, effective June 1, 2011, drs10h.pdf, at 11.

187 Arizona Child Support Guidelines, Adopted by the Arizona Supreme Court, effective January 1, 2006, 2005CSG.pdf [2005 Guidelines] at page 10:

A. Each block of time begins and ends when the noncustodial parent receives or returns the child from the custodial parent or from a third party with whom the custodial parent left the child. Third party includes, for example, a school or childcare provider.

B. Count one day of parenting time for each 24 hours within any block of time.

C. To the extent there is a period of less than 24 hours remaining in the block of time, after all 24hour days are counted or for any block of time which is in total less than 24 hours in duration:

1. A period of 12 hours or more counts as one day.

2. A period of 6 to 11 hours counts as a half-day.

3. A period of 3 to 5 hours counts as a quarter-day.

5. Periods of less than 3 hours may count as a quarter-day if, during those hours, the noncustodial parent pays for routine expenses of the child, such as meals.

$188 \quad$ Id. at 11.

1892005 Arizona Guidelines, Appendix A. The simplest way of thinking about this is to subtract the smaller amount due from each parent from the larger one and divide by 2 . 
Even a preliminary examination of these 2008 court documents reveals at least two worlds. ${ }^{190}$ The first is a world involving divorcing, relatively wealthy parents. For these wealthier once-married parents, 27 percent indicate that they have equal custody, and the average parenting time adjustment ${ }^{191}$ exceeds 122 days a year, or $33 \%$ of the total time. The norm for these parents is clearly to share custody, ${ }^{192}$ and in those equaling or exceeding the median income of mothers (\$2300 a month), ${ }^{193}$ substantial parenting time is quite routine. The marriages usually dissolve by consent decree, so that $50.6 \%$ had agreed-upon orders that both dissolved the marriage and set custody. ${ }^{194}$ They did not often have post-decree court modifications - 56.4\% had one or no appearances. ${ }^{195}$

For less wealthy, married Maricopa parents (those with less than the median mother's income), only 9.4\% featured equal custody, and the average amount of parenting time enjoyed by the parent without primary custody is just over 97 days, or $26 \%$ of the time (with a reduction in child support of $26.1 \%$ ). ${ }^{196}$ The pattern of divorce was different as well, reversing the practice of the wealthier parents. The predominating dissolution $(42.8 \%)$ was by default. ${ }^{197}$

190 The same startling results are obtained if mother's income is divided by quintiles: lowest 98.63 days; fourth 100.855 days; $3^{\text {rd }} 107.068$ days; $2^{\text {nd }} 121.143$ days and highest 124.049 days.

$191 \quad$ More than $94 \%$ of the child support worksheets indicated such an adjustment.

192 Joint legal custody, or shared decisionmaking, was part of the plan for $73 \%$ of the couples.

193 There were several reasons to consider the income of mothers rather than fathers. First, in cases with very low maternal income and high paternal income, it would be unusual not to have a primary caretaker. Second, I knew that maternal, but not paternal, income was related to custody time. Third, using the total child support amount would be misleading because there were frequently deductions for other children supported by mothers and/or fathers. The gross income figures eliminated this concern. $194 \quad 28.8 \%$ had default dissolutions, and $13.5 \%$ had a decree of dissolution following a trial. Another way of discriminating in the data is by looking at Hispanic surnames. The classic article suggesting that this is the appropriate way to identify Hispanic or Latino families (used by the Census Bureau, is David L. Word et al., "Demographic Aspects of Surnames from Census 2000," (2008). Available at http://www.census.gov/genealogy/www/surnames.pdf.) In the wealthier, married group $25.2 \%$ of the couples had at least one with a common Hispanic surname (that is, with over $70 \%$ likelihood that the person using it would self-identify as Hispanic according to the 2000 census). For the less wealthy, married couples it was $36.7 \%$, nearly the same as for the custody group (37.2\%), but still lower than the support group, where $49.7 \%$ had at least one common Hispanic surname. See Marc N. Elliott et al., Using Indirect Estimates Based on Name and Census Tract to Improve the Efficiency of Sampling Matched Ethnic Couples from Marriage License Data, 77 Pub. Opinion Q. 375 (2013). Ethnicity is important because it is possible that with this population social norms might run toward mother-caretaking, and also because information about the real possibility of judges' ordering equal or substantially shared custody may not be effectively communicated to the Hispanic parents. Hispanic parents may be less likely to elect shared parenting. See Christine Linquist, Nord \& Nicholas Zill, Non-Custodial Parents' Participation in their Children's Lives: Evidence from the Survey of Income and Program Participation, vol. 1, at 12 (1996), available at fatherhood.hhs.gov/SIPP/NonCusp1.htm.

195 The corresponding number for the lower income married couples was $58.9 \%$, though the single most litigious, with 25 court entries following dissolution, was in this group.

196 Joint legal custody was part of the order or plan in $57.8 \%$ of these couples.

197 Default dissolutions occur when the other party is served but does not contest, or is reached only by publication. In default dissolutions, the petitioner is granted whatever was established in the complaint (or has been agreed to previously by the other). Consent dissolutions constituted only $26.7 \%$, and dissolutions by decree again were $15 \%$. 
The difference becomes yet starker for unmarried parents. Again, there are two groups. One involves actions to establish support, which are usually (though not always) initiated by the state to collect arrearages or reimbursement for public assistance. In these cases, the median (and mode, or most frequently recurring amount) mother's income was $\$ 1196$ per month, not coincidentally that attributable to minimum wage (the figure utilized to calculate TANF, or public assistance). Only 3, or $2 \%$ of these couples, indicated equal parenting. Further, only $34 \%$ of these couples indicated any parenting time adjustment to child support at all, and the average amount for this third was 77 days only, or slightly more than $20 \%$ of the time (justifying a reduction of $10.5 \%$ in child support).

The other unmarried group involved actions for custody, parenting time and support. Fathers most often brought these suits, and many had established paternity through the hospital's paternity program and had been listed on the child's birth certificate. While they were not wealthy - the mother's median income was $\$ 1500$ a month-more than $71 \%$ of the parents had an adjustment for parenting time on the worksheets, and parenting time averaged 101 days (both figures higher than those for than the lower income, married parents). These are, by definition, involved or at least motivated fathers, and at least some indicated relationships of longstanding, one even of twelve years. While they were not divorcing, so were not filing the associated forms, they were active following initial custody decrees, with more than half having two or more court appearances and one "outlier" boasting, if that is the right word, 33. As Pruett and DiFonzo summarize the literature, they express concern about applying studies of formerly married parents to in this group, who may be quite different. ${ }^{198}$

One other set of observations involves the role of lawyers. More than three quarters $(76.5 \%)$ of the petitioners completing divorces were not legally represented. For the respondents, $96.1 \%$ were pro per, as this is called in Arizona. A valid question asked by lay people is whether attorneys are "worth it." While they are likely to have more appearances pre-decree (averaging about two appearances in court as opposed to less than one), the average number of reappearances at or post the decree is not significantly different (3.39 for represented petitioners compared to 3.10 for the pro se). ${ }^{199}$ This is not surprising, since the mean gross incomes for the represented groups are about $\$ 500$ dollars higher for mothers and more than $\$ 2300$ higher for fathers, so that more than custody is typically at stake (\$6053.27 total gross income per month for the represented compared to $\$ 3700.49$ for the pro se). Another indication that the cases might be more complicated is that the represented group is more likely to have significant property other than homes or pensions (usually stock or additional homes), with only about $12 \%$ of the pro se parties having other significant assets compared to $26.9 \%$ of the parties

198 Pruett \& DiFonzo, supra note 11, at 155-56, 162, 166.

199 Typically in the pro se actions the post-decree petitions were to reduce child support (21\% of the self-represented cases), while in the petitioner represented cases, they were equally likely (15.2\%) to be to reduce child support or increase parenting time. Increasing parenting time, because of the adjustments to child support, would also have the effect of reducing the support. The threshold for granting a change to ordered child support is a deviation of $15 \%$ or more in the amount calculated on the worksheet. In the cases where only a reduction was sought, it was typically because the obligor's income had decreased (and/or the obligor was unemployed). 
represented by attorneys. In the support establishment cases, while the state represented the custodial parent (always the mother unless a collateral relative had custody), it was extremely uncommon to have the father represented. Likewise for the custody cases, few had representation. ${ }^{200}$

We return now to the values argued for various child custody (or parenting time) regimes. How well does a state with a large amount of shared and even a significant amount of equal custody promote continuity and stability, maximize time with both parents, and minimize conflict and violence? Are these values systematically satisfied differently for different groups?

continuity and stability. Two methods of measuring continuity and stability seem possible from this data. The first is the most obvious, appears in other literature, ${ }^{201}$ and would look at how stable custody awards remain over time. In particular, one might compare the number of motions to change parenting time (or change the parenting plan completely, say, from a sole custody plan to a joint one or from one primary residence to the other) based upon the original order (comparing primary maternal or paternal custody to equally shared custody). One might even make the comparison depend upon the number of days of parenting time. Tendencies to change custody might also depend upon income, representation (or not), age or gender of the child, and whether substance abuse or mental illness was involved with the case. ${ }^{202}$

The more difficult question considers whether the original order itself was consistent with the parenting done before separation. ${ }^{203}$ The files do not contain any direct and consistent measure of parental practices before separation. One possible indication would be that one of the spouses was staying at home to do child care. Divorcing parents do list their occupations in their complaints and responses, and some did put down "child care" or "stay at home parent" or "none" (as opposed to "unemployed"). However, the fact that one parent isn't working while the other does isn't always indicative of the childcare arrangement. ${ }^{204}$ Further, the complaints do not always contain this occupation information (and never do for support cases, at least for the non-paying parent). A more reliable indication may be gross wage differences between the parents, since marriages are typically assortative (so that the spouse will have comparable education and other human capital) ${ }^{205}$, while staying out of the labor

\footnotetext{
$200 \quad 8 / 43$ were represented.

$201 \quad$ Maccoby \& Mnookin, supra note 78, Melli and Brown, supra note 49, Reynolds, supra note 129 all refer to "maternal custody drift".

202 Post-decree discovery or incidence of child abuse by a parent or partner might also result in parenting time modifications, but there were a very small number of these cases.

203 This is, of course, the default of the ALI Principles, supra note 9, $\S 2.07$ for parents who cannot agree on a parenting plan. The intuition is that absent the preferred agreed-upon plan, the second best solution is to approximate whatever the parents were doing before.

204 In fact, some older literature indicates that unemployed Hispanic fathers, in particular, are less

likely to do child care or housework for psychological/cultural reasons; that to assume women's work would threaten masculine identity.

205 GARY S. BECKER, A TREATISE ON THE FAMILY (2d ed., 1991). Recently, see Elizabeth McClintock, Beauty and Status: The Illusion of Exchange in Partner Selection, 79 AM. SOC. REV. - (2014).
} 
force to care for dependents or working part time has a permanent negative effect on income. $^{206}$

However well this may work for married couples or for long term cohabitants (those who file custody actions), ${ }^{207}$ it is unlikely to describe many unmarried couples, both of whom may be unemployed or employed at minimum wage regardless of child care obligations. One would assume that for these couples, a move toward equal custody of a young child would present a great and perhaps threatening break in continuity. (On the other hand, if a third party, such as an aunt or grandmother, is providing the child care while the parents work there may be little or at least a smaller dampening effect on wages.) The strongest case for a lack of continuity may be for couples who did not live together after the birth of the child, who has been living with one parent only from birth.

Once the initial order has been made and some time has passed, a new continuity arises (or the original one, whatever he parents were doing prior to separation continues, is strengthened). The child or children becomes used to the new pattern of spending time with the parents, as well as accustomed to the neighborhood (or neighborhoods), school, after school friends, and so forth. Some parents want to relocate to some distance away, claiming employment opportunities for themselves or a new spouse, the need to be closer to families of origin, and so forth. These cases are frequently litigated, especially if the parents have been sharing parenting time (and have joint legal custody) A primary parent may well claim that necessary relocation permits the primary relationship to remain stable and continuous. The parent who would be left behind claims (even if there can be no claim based on equal custody or parenting time), that the neighborhood and friends and school will all be lost. One famous case also pointed out that relocation would threaten the fragile relationship between father and child. ${ }^{208}$ If the noncustodial parent has been faithfully spending the ordered time, courts may be reluctant to permit the move. ${ }^{209}$ As with several features of equally shared custody, geographic restrictions may be particularly hard on the less wealthy participants in the labor force, who usually move to take advantage of employment. The impact will be most keenly felt by immigrants, particularly seasonal employees or those without documents.

The second major value going into Arizona's best interest of the child consideration is to maximize time with both parents. This was clearly a function of statutory revisions in 2010 and 2013, but shared custody seems to have been a feature of

206 See, e.g., Joni Hersch, Opting Out Among Women with Elite Education, Vanderbilt University Law School Law and Economics Working Paper 13-05 (2013), available at http://papers.ssrn.com/sol3/papers.cfm?abstract_id=2221482; Heather Boushay, Opting Out: The Effect of Children on Women's Employment in the United States, 14 FEMINIST ECON. 1 (2008).

207 Some of the custody (624) complaints stated that fathers had done the primary caretaking while the couple lived together, in one case, for twelve years. Some of these couples had informal equal parenting plans that were only now being threatened.

$208 \quad$ Marriage of Lamusga, 88 P.3d 81 (Cal. 2006).

209 See, e.g., H.A. v. A.A., No. 03A01-1308-DR-354 (Feb. 5, 2014 Ind. Ct. App.)(mother's wish to move to Hawaii with new husband, though in good faith, was not in best interests of child). 
Arizona cases even by 2008. ${ }^{210}$ Generally, it may be worth discussing whether such a value should be imposed when not constitutionally required (as in Loving v. Virginia ${ }^{211}$ or Brown v. Board of Education ${ }^{212}$ ), where groups were grouped based upon race. Maximizing time with both separating parents equally does not seem to present courts with a similar constitutional question, and the child's interests may outweigh the parents'. In Iowa, where the legislature (over the objection of the judiciary and family law Bar), enacted presumptive shared parenting time, the Supreme Court in Hansen v. Hansen $(2007)^{213}$ declared that the child's best interests still must be considered in every case, so that basing a decision on a single factor only is not appropriate.

Shared parenting time has been felt to be appropriate for children in many states for some thirty years so long as it's requested by both fit parents. ${ }^{214}$ One critique of mediation brought by feminists was that mediators were punishing parents who did not to conform to their preferred method (shared parenting) by awarding, or threatening to award, primary custody to the other parent. ${ }^{215}$ With the 2008 sample, we can examine how frequently shared parenting would have been selected anyway by considering whether it is more or less frequent when mediation is used to settle the case. ${ }^{216}$ Another

210 The median amount of parenting time enjoyed by the divorcing parent with the smaller share is 99 days in Pima County and 106 days in Maricopa. The fact that the mean is so much higher in Maricopa (111 days) is driven by the large number of equal custody cases in that jurisdiction. (It is also 99 days in Pima County, for the equal custody cases are balanced by a number of cases in which one parent did not receive any time at all for various reasons).

211388 U.S. 1 (1967).

$212 \quad 347$ U.S. 483 1954).

213733 N.W.2d 683 (Iowa 2007).

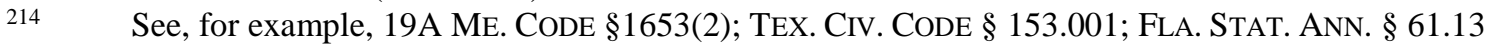

(c) (2010). Some statutes explicitly require that it be logistically possible given the parents' incomes, ability to cooperate, and locations.

215 Grillo, supra note 36.

216 Compared to an overall median of 109 days for the spouse who was not the primary custodial parent, the mediated cases had a median of 143 days, which is a statistically significant difference. The means were also statistically significantly different at $p<.01$ (107 versus 130 days). If the mediated result turns out to work less well than the non-mediated, there may be a problem with the automatic referrals whenever parties do not agree. And it does. The 62 mediated divorce cases were significantly $($ at $p<.001)$ more likely to have more post-decree appearances ( 2.4 for non-mediated compared to 5.84 mediated), postdecree motions for more (.09/.306) or less (.063/.226) custody, decreases $(.157 / .323)$ or increases $(.067 / .242)$ in child support, and enforcement of child support (.11/.258) or visitation (.033/.097) than the 300 not referred to mediation. These rather large differences of at least $200 \%$ suggest as well that the temporary gains for the court system may be offset by the later problems in the contested custody cases that are automatically referred. Of course they are not causative-mediation does not necessarily create the problems (though the larger number of days of parenting time may). While the number of days of parenting time increased with mediation, the tendency for equal custody did not (Pearson's $\mathrm{R}=.311$; Spearman correlation $=.475$ ). In contrast, the contested divorces (DDIs) for Maricopa did not have many significant consequences in post-decree litigation. While the number of appearances was higher $(.20$ compared to .121 for default or consent decrees), this was apparently only due to the slightly higher incidences of motions to reduce (.292 compared to .169 and enforce (.229 compared to .12) child support, not custody or visitation changes.

Days of parenting time with or without mediator involvement: Maricopa completed divorces with children 
possibility is to see whether the frequency is affected when either parent brought up domestic violence (at least alleging that it had occurred during the marriage) either as part of the original pleading or at any rate before divorce. Surprisingly, the mean number of parenting days was almost exactly the same. ${ }^{217}$ Finally, there were some cases where both spouses asked for sole custody in their original complaint and answer. ${ }^{218}$

Relatedly, there is the important goal of minimizing the child's exposure to conflict. ${ }^{219}$ From the Maricopa court files dataset we cannot directly measure the impact of conflict upon children any more than we can look at the positive effects of shared parenting. ${ }^{20}$ Nor can we directly measure conflict's impact on the parents. ${ }^{221}$ There are some indirect measures of conflict. One is a consideration of post-decree domestic violence petitions. These are less likely to be strategic since domestic violence militates against shared parenting only at the time of the original order, and will not by itself justify a change in the parenting time schedule (though there may be a change to a neutral or supervised place for the exchange). In a simple binomial regression, (meaning that the dependent variable, whether there was one or more post-decree petitions for protective

\begin{tabular}{|l|r|r|r|}
\hline Mediator involved & Mean & $\mathrm{N}$ & \multicolumn{1}{c|}{ Std. Deviation } \\
\hline .0 & 106.653 & 229 & 55.4786 \\
1.0 & 129.830 & 53 & 48.6786 \\
Total & 111.009 & 282 & 54.9375 \\
\hline
\end{tabular}

217 This either suggests that parties are not filing for protective orders strategically or that courts are for the most part ignoring allegation of domestic violence. The mean number of parenting days in completed divorces involving protective orders or allegations of violence in complaint or answer was 110 days. For those without, the mean number was 111.18 .

218 There were not many of these (9). In one, the court awarded split custody. In another, the father was eventually going to be completely disabled by his Lou Gehrig's disease. In a third, the court awarded equal joint custody and the parties divorced by consent decree (prepared by father). No child support was ordered because of the equal custody. The mother ended up with the marital home, paying $\$ 45 \mathrm{~K}$ to father to equalize. The parties were so low income that any award of child support would have exceeded their ability to pay; both had been living in the marital home and neither wanted to move.

$219 \quad$ See, e.g., Pruett \& DiFonzo, supra note 11, at 164:

The think tank experts agreed that, when either or both parents have been violent through physical, verbal, or psychological abuse of the other parent, a comprehensive assessment is necessary before a shared parenting plan is considered. A substantive body of research makes clear how destructive such violence can be to parents' ability to raise their children with the requisite sensitivity and structure that promotes victim and child safety and well-being. In addition to diminishing parenting capacity, family violence negatively affects children's well-being directly. When children are directly involved in the conflict or are the subjects of it, the probabilities for their healthy development are far worse.

220 As previously mentioned, conflict and especially children's exposure to it is agreed by academics to have negative consequences for children. See, e.g., Elrod \& Dale, supra note 27; Elster, supra note 77 , and sources cited in notes 90 and 93, supra. There were occasions where judges or child welfare professionals wrote that the child was having problems largely because of the parents' continued litigation or bitterness, but nothing systematic.

221 There was anecdotal information in the files about parents' cashing out retirement funds to meet legal obligations or seeking professional help to deal with the continued stress of the divorce. 
orders, can be answered yes or no) predicting .06 of the variance, shows that the more equal the parenting time (by the number of days of adjustment in child support), the more likely there was to be a protective order request, holding constant median household income in the census tract ${ }^{222}$ and whether or not the parties were represented. The exponents signify that each additional day of parenting time beyond 109 (the mean) was associated with an additional $1 \%$ likelihood of a post-decree protective order. This is a troubling finding. ${ }^{223}$ Note that it is the unrepresented (pro per) couples who are considerably likely to file for these orders, perhaps because they cannot afford representation in seeking a modification of parenting time. ${ }^{224}$

\begin{tabular}{|l|l|l|l|l|}
\hline Variable & B & S.E. & Sig. & $\operatorname{Exp(B)}$ \\
\hline $\begin{array}{l}\text { Days of parenting to } \\
\text { time }\end{array}$ & .011 & .005 & .016 & 1.011 \\
\hline $\begin{array}{l}\text { Median household } \\
\text { income }\end{array}$ & .000 & .000 & .022 & 1.000 \\
\hline Pro per (no attorney) & .802 & .474 & .090 & 2.229 \\
\hline Constant & -5.566 & .970 & .000 & .004 \\
\hline
\end{tabular}

Another indirect way of detecting conflicted couples is to see whether motions for temporary custody or changes in custody and/or child support were contested. This can be done by noting the number of court documents entitled RES (for response) and seeing if the number of parenting time days is different for the two groups (or vice-versa). While the difference here is not statistically significant, ${ }^{225}$ motion-contested cases before the decree are associated with more orders (of almost all types) after the decree. ${ }^{226}$ While contesting various actions ${ }^{227}$ does not mean that the parties are physically violent, it does show a willingness to spend money and time, including the court's, in an attempt to thwart what the other is doing or seeking. While motions for reductions in parenting time

222 Neither the gross income of the mother nor the father was statistically significant.

223 It might indicate that the screens for violence at initial hearings were not accurate and/or that additional opportunities given by the frequent exchanges of the child created more opportunities for conflict. In one case in which the former apparently occurred, the trial court awarded equal custody because the father in question hadn't abused the parties' child, but only the mother's older child. 224 Most jurisdictions have consciously made filing for protective orders relatively simple and low cost.

225 Fewer days were awarded in the conflicted cases (111 to 104, but this isn't statistically significant). Only $5 / 44$ contested cases $(11.4 \%$ ) had equal custody at the time of decree, compared to $56 / 295(19 \%)$ of the less contested. This is actually an encouraging sign that the courts aren't awarding equal custody often in the cases where it is least likely to be successful.

226 There were statistically significantly more post decree motions (.132 of the cases compared to .136 of them), motions for decreases (.157 to .386) and increases (.075 to .250) in child support, motions to reduce parenting time (.072 to .227$)$ to enforce child support (.110 to .318) or visitation (.035 to .114), and postdecree protective orders (.069 to .205$)$.

227 I do not include an answer to the original divorce decree. Some of these corrected things like children's birthdays or the dates of the marriage, asked for a reversion to a pre-marriage surname, or specified particular assets that had been left out of the complaint. An answer also makes a default decree possible if the parties have worked out a parenting plan and property settlement, as many couples had, or dissolution by consent if that was sought. It also gives jurisdiction for support and custody actions when one spouse was out of state. 
were significantly correlated with the number of days ordered, the significance disappears once the mother's gross income is included. ${ }^{228}$

A rather obvious check is on the number of court actions post decree. This is not significantly correlated with parenting time, ${ }^{229}$ nor is the assignment of a parenting coordinator, which happens in the most contested cases. ${ }^{230}$ The cases in which one parent at least allegedly had drug, alcohol or mental illness problems were some of the most litigated in the sample. One reason for this is that in the substance abuse cases, frequent negative drug testing (TASC, using hair) was often a requirement to avoid or be freed from supervised visitation. ${ }^{231}$ Another is that drug violations are typically criminal, and all serious deficiencies on the part of the parent may be enough not only to reduce or suspend custody but also to involve the child protective system. ${ }^{232}$ Finally, in the substance abuse cases anyway, not being entirely truthful is part of the symptomatology. ${ }^{233}$

\section{Contested Custody Cases}

The small proportion of divorcing couples who end up in court could be quarreling about many things. While custody may be a factor, so may be ownership of a house or business or pension plan (or even, in some cases, the family dogs). However, of the 49 Maricopa cases where the divorce was granted after a hearing, 47 involved custody issues that could not be resolved by the parents even at the $11^{\text {th }}$ hour. ${ }^{234}$ In 33 of

228 Cox \& Snell R2=.041. Court actions post/decree

\begin{tabular}{|l|r|r|r|r|}
\hline & B & S.E. & Sig. & $\operatorname{Exp}(\mathrm{B})$ \\
\hline daysparentingtime & .005 & .004 & .155 & 1.005 \\
PWCgrossincomemother & .000 & .000 & .018 & 1.000 \\
Constant & -3.320 & .550 & .000 & .036 \\
\hline
\end{tabular}

229 It is, however, correlated significantly with higher total amounts of support ordered.

230 There is no statistical correlation between having equal custody and the assignment of a coordinator, either. What is correlated significantly are the traditional "fault" grounds for divorce: adultery, substance abuse, and pre-decree protective order claims of domestic violence.

231 In Maricopa, 18 cases required TASC testing. In Pima County, only 5 cases required TASC testing.

232 Twelve of the Maricopa County cases involved CPS investigations; of these a third involved drug or alcohol abuse.

233 Dorothy Roberts, in ShATtered Bonds: THE COLOR OF CHILD WELFARE (2001) has made the point that the child welfare system tends to be more involved with families of color than otherwise, and that the presence of social workers in the community itself may exacerbate social problems. See also Dorothy H. Roberts, Child Welfare's Paradox, 49 WiLliaM \& MARY L. REV. 881-901 (2007).

$234 \quad$ More than a quarter $(26.9 \%$, or 94 of 404) of the Pima County divorce cases were contested, and nearly half of these (43) involved competing claims for custody from the start. Contested actions were statistically significantly likely to be referred to a mediator $(.380, \mathrm{p}<.001)$ and were even more closely associated with requiring a child custody evaluator or an interview with the child $(.402, \mathrm{p}<.001)$. After dissolution, they continued to display conflict, with significantly more motions to increase custody (.258, $\mathrm{p}$ $<.001)$ or decrease it $(.292, \mathrm{p}<.001)$ or child support $(.169, \mathrm{p}<.001)$, or, notably, post-decree complaints 
these cases, the responding parent had filed an answer (spending \$269 to do so). And in 32 of those 33, the responding parent asked for a different custody arrangement than had the parent who filed for dissolution. At the extreme, each parent asked for sole custody in him- or herself, with no visitation (or restricted visitation) to be granted to the other parent. Sometimes one wanted sole custody while the other sought joint legal custody and reasonable visitation. Sometimes they disagreed from the start of the divorce action $^{235}$ over which of them should be the primary custodian. In most cases, court procedures or the judge personally forced the parents into mediation or conciliation to try to get them to settle the custody action. They also attended mandatory parenting classes and sometimes classes for high conflict couples. But they could not agree to work as a team even though they had been told that conflict was hard on their children. Because they staked out their positions early, it does not seem that the process or their attorneys encouraged their views (and most parents, in fact, were not represented).

Eventually, one or the other parent usually won, meaning that what they'd asked for in the complaint was granted by the trial court. Sometimes the decisionmaking court needed the help of custody evaluators, who might even interview the child to ascertain the child's feelings. Frequently the court took the custody decision "under advisement," meaning that the parents did not know the outcome until some time (hours or days) later. In the vast majority of cases, after fighting these fierce battles, the parents were supposed to get over their hostility and co-parent. ${ }^{236}$ In many they would need to exchange the children frequently (sometimes at the police station). In four, the court granted them equal custody even though neither had asked for it. In several cases, the children ended up being abused by a parent during custodial time or by his or her partner. In more than a few, domestic violence continued after the divorce.

While some of these cases disappeared from the legal landscape after the terms were declared, many continued to litigate, some until April of 2014. They continued conflict over child support, enforcement of the parenting schedules (including tardiness or refusal to open the door), and a number had post-decree domestic violence incidents. Sometimes the litigation involved payment for counseling of the children. In one case the court moaned that the children would do better in school if they weren't subjected to the continual stress of parental bickering. A child coordinator wrote in one report that the "parties are observed in communication dynamic of distrust, hostility and accusation."

One of the assumptions of those arguing for shared parenting is that the cases involving domestic violence can be screened out early in the process. In Arizona, while

of domestic violence $(.323, \mathrm{p}<.001)$. There was no significant correlation with the incomes of either mother or father, nor with the number of parenting time days (96.6 days for contested cases, 100 for uncontested), and only slightly with either parent's being represented $(-.105, \mathrm{p}<.10)$. About $20 \%$ of the contesting parents had equal custody in the dissolution decrees compared to $24 \%$ of the less contentious cases. These were more likely to have had court ordered equal custody (.294 did, compared to .139 in the remainder of the cases, $\mathrm{p}<.10$ ), and far more likely to have motions for less custody on the other parent's part (.353 compared to .087, $\mathrm{p}<.001)$.

235 On occasion, the parties were still living together at the time of filing.

236 Of the 39 contested custody Pima cases, only $25 \%$ had less than 60 days of parenting time, and $50 \%$ had more than 180 days. 
the judges were successful in doing this a number of times, in some they were not. More than half the contested cases (25/47) involved at least alleged domestic violence (and some had two or more protective orders upheld after hearings). In one, where a mother gave up her claim for sole parenting on the day of trial, the judge asked the father to leave the courtroom, went through the questions again, and decreed that she had voluntarily decided to share custody. Substantial domestic violence operates as a factor in Arizona only against shared decisionmaking (legal custody), not shared parenting time. ${ }^{237}$

Clearly, public policy in Arizona and many other states disfavors false accusations of domestic violence or abuse. ${ }^{238}$ It is important, therefore, not to give incentives to claim abuse in order to get custody (or property or revenge). But indications of drug or alcohol abuse or mental illness and particularly pre-decree domestic violence together predict many of the cases of post-decree domestic violence. ${ }^{239}$ These cases seem to call for early intervention, better screening, and some solution other than substantially equal parenting.

\section{Some Early Conclusions}

Contrary to some of the academic literature, the Maricopa cases reveal little evidence of either complaints of domestic violence in order to escape shared parenting or of allegations that a primary custodial parent was alienating the child. ${ }^{240}$ But the incidence of domestic violence correlating with increased parenting time certainly

237 If the parent who committed an act of domestic violence is seeking parenting time, that parent has to prove to the judge that parenting time will not endanger the child or significantly harm the child's emotional development. The judge may place conditions on parenting time that best protects the child and the other parent from further harm. Ariz. Rev. Stat. § 25-403.03(F). In the cases I examined, children were sometimes exchanged at police stations, for example.

238 See, e.g., ARIZ. STAT. § 25-403 (11) (making false reporting a factor against the award of legal decisionmaking or parenting time); and Ariz. Stat. § 13-2907.02 (making false reporting of child abuse a misdemeanor). Other states have similar rules. See, e.g., in New York, Karen PP v. Clyde QQ, 197 A.D.2d 753 (3rd Dept. 1993) (award of custody to the parent falsely accused); N.Y. PENAL LAW § 240.50(4); Cal. Fam. Code $\S 3022.5$ (a motion for reconsideration of existing child custody order will be granted if based on the fact that the other parent was convicted of falsely accusing the moving parent of child abuse); 325 ILL. CONS. STAT. § 5/4 (knowingly filing a false report is a misdemeanor).

239 In simple correlations, domestic violence and resolution by a court rather than default or consent is significant at $\mathrm{p}<.01$ (coefficient is .351) and substance abuse or mental illness significant at $\mathrm{p}<.01$ (coefficient is .227). A logistic regression with just these two predictors produces a Cox and Snell $\mathrm{R}^{2}$ of .102 , with each significant at $\mathrm{p}<.05$, domestic violence at $\mathrm{p}<.001$. A case is more than six times more likely (exponent is 6.61) to end up with a DDI decree if domestic violence is alleged early on and more than twice as likely (exponent is 2.32) if there's substance abuse or mental illness. In Pima, the logistic regression predicted .066 , while pre-decree domestic violence made it 7.455 times more likely that postdecree violence would be an issue (while substance/abuse/mental illness was not statistically significant). 240 The Maricopa cases contained four cases in which the noncustodial parent claimed some form of alienation: three of these claims were made by fathers. Pima had only one. In each county, there were a few POP orders that were not substantiated after hearings (with complaints made equally often by both men and women), and some cases in which the court found that domestic violence had occurred, but that it was not serious, or, in one case, was only directed to the other parent and not the child, or in another, was only directed against the father's stepdaughter. The horribles foretold by both political sides do not seem to have materialized. There was precisely one case involving enforcement of a parenting time decree in Maricopa, and 11 in Pima. 
warrants further examination, and gives one pause. It would be far less concerning if we could identify these cases in advance, but courts are not apparently consistently doing so. ${ }^{241}$

The fact that shared parenting has become the norm neither for most of the separated unmarried parents (at least not from the legal records left behind) nor for the less wealthy parents in our sample is also troubling. If shared parenting truly benefits children, that benefit should not be reserved for the wealthy, made difficult for the middle class (either logistically or because of the decreased child support owed), and certainly should not be impossible for the poor. Nor should a differential impact upon Hispanics in the sample be ignored. ${ }^{242}$ This difference (in parenting days) persists even when income is included in simple regression analysis, and is nearly as strong as the income effect. ${ }^{243}$

I began this inquiry wondering whether it was true that fathers asked for more custody than they actually wanted in order to reduce or eliminate child support payments. I did not find evidence of systematic opportunism (as I might have if there had been many motions to change custody back to a primary system after a lapse of time), but there were a handful of cases of this. I would like to track what particular judges are doing in the two counties to see if, despite the statute, there is variability in the tendency to award shared parenting. I also plan to use the current sample to question whether parents who will not pay child support when able can be identified in advance. I am also beginning to look at cases from Indiana, which had a different scheme for reducing child support based on parenting time. There might be still less evidence of "trading" going on than the small amount found in Maricopa ${ }^{244}$ or potentially less of a disparity among wealthier and poorer parents. Obviously it would be good to have either interviews with children or run a series of psycho-social tests on them, both to find out if they do truly

241 Margaret F. Brinig, Leslie Drozl \& Loretta Frederick, Perspectives on Joint Custody Parenting as Applied to Domestic Violence Cases, 52 FAM. CT. REV. 272 (2014).

242 In the Maricopa divorce sample, $14 \%$ had equal custody compared to nearly $20 \%$ for the nonHispanic sample. Even for the non-equal parenting plans, the Hispanic numbers were far (and statistically significantly) lower: 95.53 days compared to 115.28 for non-Hispanics.

$243 \quad$ The $\mathrm{R}^{2}$ predicts .044 of the variance.

\begin{tabular}{|c|c|c|c|c|c|c|}
\hline \multicolumn{7}{|c|}{ Coefficients $^{\mathrm{a}}$} \\
\hline \multirow{2}{*}{\multicolumn{2}{|c|}{ Model }} & \multicolumn{2}{|c|}{ Unstandardized Coefficients } & \multirow{2}{*}{$\begin{array}{c}\text { Standardized } \\
\text { Coefficients } \\
\text { Beta } \\
\end{array}$} & \multirow[b]{2}{*}{$\mathrm{t}$} & \multirow[b]{2}{*}{ Sig. } \\
\hline & & B & Std. Error & & & \\
\hline \multirow[t]{3}{*}{1} & (Constant) & 106.492 & 5.168 & & 20.606 & .000 \\
\hline & Either has Hispanic surname & -18.509 & 6.955 & -.155 & -2.661 & .008 \\
\hline & Mother's gross income & .003 & .001 & .158 & 2.714 & .007 \\
\hline
\end{tabular}

a. Dependent Variable: days of parenting time

244 I found 10 cases in which it may have occurred in Maricopa (numbers 72, 93, 143, 161, 188, 327, $360,480,484$ and 595). 
benefit from additional days of parenting time. While a successful legislative attempt to create still more shared parenting has been made by legislators in Arizona, it would be interesting to see whether a strong shared parenting presumption had more or less traction in a state without a track record of shared parenting. ${ }^{245}$

The law in place at the time of my study was typical of many states "friendly" to joint parenting. ${ }^{246}$ The state moved in $2010^{247}$ and again in $2012^{248}$ progressively toward equal parenting for all separating couples. ${ }^{249}$ The child support rules, again typical ones, automatically deduct from the amount a parent must otherwise pay for a scheduled parenting time adjustment. ${ }^{250}$ If the parents are equal custodians, the total amounts attributable to shared expenses at their joint income levels is equalized between the two households. ${ }^{251}$ This means that for a high earning father and lower earning mother, the

$245 \quad$ ARK. CODE $§ 9-13-101$, enacted in 2013, has very strong language mandating maximizing the time spent with each parent if requested by either or ordered by the judge. However, Arkansas is a state that until recently had a presumption against shared parenting, and it is unclear whether the statute will have much, if any, effect. Attorneys (19) answering a survey there were all aware of the new law, but nearly $60 \%$ thought that it would make a very small or small effect in practice, and all but one thought that there was less than a $40 \%$ chance that a father would be awarded equal custody before passage of the new law when the mother asked for sole custody. Afterwards, 8 thought there would be at least a $50 \%$ chance. $246 \quad$ ARIZ. REV. STAT. $\$ 25-403.01$. Sole and joint custody

A. In awarding child custody, the court may order sole custody or joint custody. This section does not create a presumption in favor of one custody arrangement over another. The court in determining custody shall not prefer a parent as custodian because of that parent's sex.

B. The court may issue an order for joint custody over the objection of one of the parents if the court makes specific written findings of why the order is in the child's best interests. In determining whether joint custody is in the child's best interests, the court shall consider the factors prescribed in section 25-403, subsection A and all of the following:

1. The agreement or lack of an agreement by the parents regarding joint custody.

2. Whether a parent's lack of agreement is unreasonable or is influenced by an issue not related to the best interests of the child.

3. The past, present and future abilities of the parents to cooperate in decision-making about the child to the extent required by the order of joint custody.

4. Whether the joint custody arrangement is logistically possible.

C. The court may issue an order for joint custody of a child if both parents agree and submit a written parenting plan and the court finds such an order is in the best interests of the child. The court may order joint legal custody without ordering joint physical custody.

CHILD CUSTODY, 2005 Ariz. Legis. Serv. Ch. 45 (S.B. 1045) (WEST).

$247 \quad$ Laws 2010, Ch. 186, § 2.

$248 \quad$ Laws 2012, Ch. 309, § 8, eff. Jan. 1, 2013

249 ARIZ. REV. STAT. $\$ 25-403.02$ now includes in part:

B. Consistent with the child's best interests in $\S 25-403$ and $\S \S 25-403.03,25-403.04$ and 25-

403.05, the court shall adopt a parenting plan that provides for both parents to share legal decision-making regarding their child and that maximizes their respective parenting time. The court shall not prefer a parent's proposed plan because of the parent's or child's gender.

$250 \quad$ The current Guidelines, adopted by the Arizona Supreme Court and effective Jan. 1, 2011, are available at https://www.azcourts.gov/Portals/31/GuideSched10072011.pdf. The appropriate tables remain at Appendices A and B.

251 The example provided in the Guidelines, supra note 223, at 13-14 is

EXAMPLE: After making all applicable adjustments under Sections 9 and 13, the remaining child support obligation is $\$ 1500$. The parents' proportionate shares of the obligation are $\$ 1000$ and $\$ 500$. To equalize the child support available in both households, deduct the lower amount from the higher amount $(\$ 1000-\$ 500=\$ 500)$, 
amount paid will be only a fraction of what he would ordinarily pay, and when the incomes are roughly equal, the ordered payment will often be zero. The difference is not made up by alimony (spousal support), which is typically less in amount than the difference in child support, and which usually ends after two or three years. ${ }^{252}$ In some cases, the mothers sharing parenting time ended up on public assistance though the fathers were living quite comfortably. ${ }^{253}$

then divide the balance in half $(\$ 500 \div 2=\$ 250)$. The resulting amount, $\$ 250$, is paid to the parent with the lower obligation.

252 While this may have been a national trend for some years, New Jersey seems to be moving in the direction of eliminating permanent alimony. The bill passed July 26, 2014, and has been sent to the governor for his signature. See http://www.njlawjournal.com/id=1202661000396/NJ-AssemblyCommittee-Approves-Major-Overhaul-of-Alimony-System\#ixzz35mnhrrua. The Bill numbers are A845, A971 and A1649, as amended.

253 Some examples are Pima 25, 277, 319 and 350, and Maricopa 210, in all of which more than 30\% was deducted from the amount fathers were otherwise to pay, and the mothers went on public assistance. The fathers' incomes varied from $\$ 2340$ a month to $\$ 3797$, and they paid from a low of $\$ 146.39$ to a high of $\$ 382$ in child support. 